January 2021

\title{
Using Extrinsic Evidence to Excuse a Liability Insurer's Duty to Defend
}

Douglas R. Richmond

Aon Commercial Risk Solutions

\section{Recommended Citation}

Douglas R Richmond, Using Extrinsic Evidence to Excuse a Liability Insurer's Duty to Defend, 74 SMU L. REV. 119 (2021)

https://scholar.smu.edu/smulr/vol74/iss1/4

This Article is brought to you for free and open access by the Law Journals at SMU Scholar. It has been accepted for inclusion in SMU Law Review by an authorized administrator of SMU Scholar. For more information, please visit http://digitalrepository.smu.edu. 


\title{
Using EXTRINSIC EvidenCE TO EXCUSE A LiABILITY INSURER'S DUTY TO DEFEND
}

\author{
Douglas R. Richmond*
}

\begin{abstract}
Most Americans and American businesses purchase liability insurance to protect against financial loss should they ever be sued. In furnishing this protection, liability insurers contractually promise policyholders that they will defend them against lawsuits seeking covered damages and indemnify them for such damages up to the policy limits. As important as the insurer's promise of indemnification is to an insured, the insurer's agreement to defend the insured in litigation is an equally essential aspect of the liability insurance bargain. An insurer must decide whether it has a duty to defend its insured at the outset of a case. There are two approaches to determining an insurer's duty to defend. First, there is the eight corners rule, under which the factual allegations in the plaintiff's complaint or petition are compared with the policy, and the insurer owes a defense only if those allegations potentially implicate the insurer's duty to indemnify the insured. Second, there is the extrinsic evidence approach. Courts employing an extrinsic evidence approach hold that an insurer must look beyond the pleadings and consider any facts brought to its attention or any facts that it reasonably could discover at the time suit was filed in deciding whether it has a duty to defend. Liability insurance policies typically provide that the insurer will pay the cost of the insured's defense in addition to the policy's liability limits. This is a potentially significant expense for the insurer because defense costs may, and often do, exceed any settlement or judgment ultimately paid. Given the expense associated with providing a defense, it is not surprising that an insurer may want to disclaim its duty to defend based on extrinsic evidence that establishes that it will have no duty to indemnify the insured. Of course, an insurer generally cannot decline to defend its insured if, in making that determination, it is limited to the facts alleged in the plaintiff's petition or complaint; after all, even in extrinsic evidence states, it usually is the allegations in that pleading that triggered the insurer's duty to defend in the first place.

Thus, insurers frequently test their ability to rely on extrinsic evidence to disclaim their duty to defend when the plaintiff's complaint or petition al-
\end{abstract}

* Managing Director, Professional Services, Aon Commercial Risk Solutions, Kansas City, Missouri; J.D., University of Kansas. Opinions expressed here are the author's alone. 
leges facts that trigger the duty. In other words, if an insurer must, in many states, consider extrinsic evidence in accepting its duty to defend, can it also rely on extrinsic evidence to deny or exit a defense? The answer, generally, is no; the use of extrinsic evidence is rarely a two-way street. As a result, even an insurance company with a solid factual defense to coverage generally must defend the insured under a reservation of rights and file a separate declaratory judgment action to establish that it will have no duty to indemnify the insured and can therefore terminate its duty to defend. From an insurer's perspective, however, that approach is of limited value unless the declaratory judgment action can be decided before the tort action against the insured concludes. In fact, such an outcome is rare. Consequently, an insurer may be forced to bear the cost of defending a lawsuit alleging uncovered claims or causes of action well after it has discovered that it will never have to indemnify the insured. Those costs get passed on to insureds through premiums. Although the general rule holds that an insurer may not rely on extrinsic evidence to refuse to defend an insured, some courts that adhere to the general rule occasionally recognize exceptions. Plus, there is a contrary minority rule. It is therefore fair to ask whether an insurer should be allowed to rely on extrinsic evidence to disclaim or extinguish its duty to defend when the plaintiff's complaint or petition alleges facts that implicate coverage, and, if so, under what circumstances? This question is timely first because of two 2020 Texas Supreme Court decisions addressing it and offering different answers based on the facts presented: Richards v. State Farm Lloyds and Loya Insurance Co. v. Avalos. Second, as Richards and Loya demonstrate, insurers' use of extrinsic evidence to excuse their defense obligations is an ongoing litigation strategy. That is not to say that the strategy is good or bad, but it is to say that the extrinsic evidence issue will continue to surface in key cases in various jurisdictions. Third, while insurers' use of extrinsic evidence to defeat the duty to defend is hotly contested by policyholders, courts that have considered the issue over the years have rarely discussed it in meaningful fashion in their opinions. The resulting lack of guidance hampers courts either confronting the issue for the first time or entertaining reconsideration of prior holdings. This Article provides that guidance.

\section{TABLE OF CONTENTS}

I. INTRODUCTION ............................. 121

II. THE TEXAS CASES AND THEIR BROADER IMPLICATIONS.

A. The Effect of "Groundless, False, or

Fraudulent" Language Qualifying the Duty to

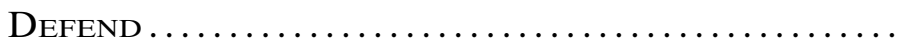

1. The Richards Case ........................ 129

2. Analyzing Groundless-Claims Clauses More Broadly ............................... 
B. Collusion as Justifying the Use of Extrinsic Evidence to Defeat the Duty to Defend ....... 140

1. Along Comes Avalos ......................... 140

2. Analysis ............................. 144

III. RULES FOR THE USE OF EXTRINSIC EVIDENCE TO EXCUSE AN INSURER'S DUTY TO DEFEND .... 146

A. General Guidance Concerning the Use of Extrinsic Evidence ....................... 146

B. Specific Instances Justifying the Use of

Extrinsic Evidence Related Solely to

Coverage to Excuse the Insurer's Duty to

DEFEND ..................................... 147

1. The Party Seeking a Defense Is Not an Insured.... 148

2. The Vehicle or Other Property Involved in the Occurrence Is Not Covered Under the Policy in Question ...................................

3. The Underlying Harm Occurred Outside the Policy Period.................................... 152

4. Lateness Under a Claims-Made-and-Reported or Claims-Made Policy ........................ 153

5. Collusion or Other Lack of Cooperation.......... 155

C. Incontrovertible Evidence Establishing A

Coverage Defense.......................... 155

1. Criminal Conviction Establishing an Intentional Injury ................................... 156

2. Criminal Conviction Perfecting a Related Exclusion

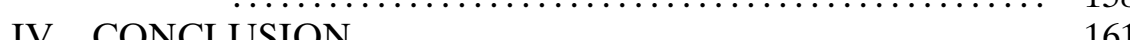

\section{INTRODUCTION}

$\mathrm{L}$ IFE is uncertain; accidents happen, and seemingly innocuous decisions sometimes produce unintended consequences. When someone is injured or killed, or property is damaged or destroyed as a result, litigation to hold alleged wrongdoers accountable commonly follows. Recognizing these possibilities, most Americans and American businesses purchase liability insurance to protect against financial loss in the event they should ever be sued. ${ }^{1}$ In furnishing this protection, liability insurers contractually promise policyholders that they will defend them against lawsuits seeking damages covered by their policies and indemnify

1. See Tom Baker \& Kyle D. Logue, In Defense of the Restatement of Liability Insurance Law, 24 Geo. MAson L. Rev. 767, 767 (2017) ("For most non-contractual legal claims for damages that are brought against individuals or firms, there is some form of liability insurance coverage."); Kenneth S. Abraham, Tort Luck and Liability Insurance, 70 RutGers U. L. REV. 1, 10 (2017) ("[R]oughly three-quarters of commercial and organizational defendants' potential liabilities are covered by liability insurance."). 
them for such damages up to the applicable policy limits. ${ }^{2}$ As important as the insurer's promise of indemnification is to an insured, the insurer's agreement to defend the insured in litigation is an equally essential aspect of the liability insurance bargain. ${ }^{3}$

An insurer must decide whether it has a duty to defend its insured at the outset of a case. ${ }^{4}$ Unlike an insurer's duty to indemnify, which requires coverage under the policy in question, ${ }^{5}$ the duty to defend attaches where there is merely the potential for coverage. ${ }^{6}$ In deciding whether there is the potential for coverage and thus whether an insurer owes a duty to defend, courts resolve any ambiguities or doubts in favor of the insured. ${ }^{7}$ As a result, an insurer may have a duty to defend an insured even though it ultimately has no duty to indemnify the insured. ${ }^{8}$ To capsulize matters, an "insurer has a duty to defend any lawsuit alleging claims against its insured for which, if liability were later established, the

2. See, e.g., Ins. Servs. Office, Inc., Commercial General Liability Coverage Form (CG 000104 13), at 1 (2012) [hereinafter CGL Coverage Form] ("We will pay those sums that the insured becomes legally obligated to pay as damages because of 'bodily injury' or 'property damage' to which this insurance applies. We will have the right and duty to defend the insured against any 'suit' seeking those damages."); Ins. Servs. Office, Inc., Homeowners 3-Special Form (HO 000305 11), at 17 (2010) [hereinafter Homeowners 3-Special Form] ("If a claim is made or a suit is brought against an 'insured' for damages because of 'bodily injury' or 'property damage' caused by an 'occurrence' to which this coverage applies, we will: . . . [p]ay up to our limit of liability for the damages for which an 'insured' is legally liable. ... and ... [p]rovide a defense ... even if the suit is groundless, false or fraudulent.”); ISO Props., Inc., Personal Auto Policy (PP 000101 05), at 2 (2003) [hereinafter Personal Auto Policy] ("We will pay damages for 'bodily injury' or 'property damage' for which any 'insured' becomes legally responsible because of an auto accident. ... We will settle or defend, as we consider appropriate, any claim or suit asking for these damages.") (all policies on file with the author).

3. See Campbell v. Super. Ct., 52 Cal. Rptr. 2d 385, 392-93 (Ct. App. 1996) ("[I]nsurance is purchased to provide the peace of mind and security that comes from knowing that if the insured contingency arises, the insurer will defend against the claim. Stated another way, one of the primary benefits of an insurance policy is that the insured can expect the insurer to defend against third-party claims."); Pine Oak Builders, Inc. v. Great Am. Lloyds Ins. Co., 279 S.W.3d 650, 655 (Tex. 2009) ("A defense of third-party claims provided by the insurer is a valuable benefit granted to the insured by the policy, separate from the duty to indemnify."); Woo v. Fireman's Fund Ins. Co., 164 P.3d 454, 459-60 (Wash. 2007) ("The duty to defend is a valuable service paid for by the insured and one of the principal benefits of the liability insurance policy.").

4. See Allen v. Bryers, 512 S.W.3d 17, 31 (Mo. 2016) ("The duty to defend arises only when there is a possibility or potential for coverage at the outset of the case.").

5. Thee Sombrero, Inc. v. Scottsdale Ins. Co., 239 Cal. Rptr. 3d 416, 420 (Ct. App. 2018) (quoting Advanced Network, Inc. v. Peerless Ins. Co., 119 Cal. Rptr. 3d 17, 23 (Ct. App. 2010)); Mt. Hawley Ins. Co. v. Casson Duncan Constr., Inc., 409 P.3d 619, 621 (Colo. App. 2016); Robbins v. Mason Cnty. Title Ins. Co., 462 P.3d 430, 435 (Wash. 2020).

6. S. Tr. Ins. Co. v. Mountain Express Oil Co., 828 S.E.2d 455, 458 (Ga. Ct. App. 2019); Core Constr. Servs. of Ill., Inc. v. Zurich Am. Ins. Co., 126 N.E.3d 694, 700 (Ill. App. Ct. 2019); Merrick v. Fischer, Rounds \& Assocs., Inc., 939 N.W.2d 795, 807 (Neb. 2020).

7. Erie Ins. Exch. v. Moore, 228 A.3d 258, 265 (Pa. 2020); Webb v. USAA Cas. Ins. Co., 457 P.3d 1258, 1265-66 (Wash. Ct. App. 2020); Choinsky v. Emps. Ins. Co. of Wausau, 938 N.W.2d 548, 555 (Wis. 2020).

8. Lua v. QBE Ins. Corp., 421 F. Supp. 3d 1082, 1089-90 (D. Colo. 2019) (applying Colorado law); U-Haul Co. of Mo. v. Carter, 567 S.W.3d 680, 685 (Mo. Ct. App. 2019) (quoting Arch Ins. Co. v. Sunset Fin. Servs., Inc., 475 S.W.3d 730, 733 (Mo. Ct. App. 2015)); ZRZ Realty Co. v. Beneficial Fire \& Cas. Ins. Co., 266 P.3d 61, 66 (Or. 2011). 
insurer would be required to indemnify the insured."9

There are two approaches to determining an insurer's duty to defend. First, there is the so-called four-corners or eight-corners rule, also known as the complaint allegation rule or the exclusive pleading rule. ${ }^{10}$ Under what we'll call the eight-corners rule, the factual allegations in the plaintiff's complaint or petition are compared with the policy, and the insurer owes a defense only if those allegations potentially implicate the insurer's duty to indemnify the insured. ${ }^{11}$ As the explanation of the rule indicates, the "eight corners" describe the four corners of the complaint or petition combined with the four corners of the insurance policy. ${ }^{12}$ Under the eight-corners rule, facts outside the pleadings are not material to the determination of the insurer's duty to defend. ${ }^{13}$

The eight-corners rule is simple and easy to apply. ${ }^{14}$ Courts that favor the rule further reason that it "serves a salutary purpose" by preventing courts "from conducting an intensive factual analysis at an early stage of the proceedings, which would only increase litigation costs and needlessly tax parties and courts before the underlying suit had barely begun." 15 On the other hand:

[T] he eight corners rule places the insured at the mercy of the lawyer drafting the complaint or petition .... The drafting lawyer, whether through ignorance or carelessness, may not allege known facts potentially implicating coverage and thus triggering the insurer's duty to defend. An insured should not be denied a valuable defense because of a plaintiff's cursory, vague, or unartful pleading. In short, a third-party claimant should not be allowed to determine the insured's rights under its insurance policy.

[Additionally], the eight corners rule promotes collusion between insureds and plaintiffs. An insured who fears being undefended can approach the plaintiff with a copy of her insurance policy and help the plaintiff craft a complaint or petition ... that is sure to trigger the insurer's duty to defend. Such behavior has untold economic conse-

9. Robert H. Jerry, II \& Douglas R. Richmond, Understanding Insurance LAw 694 (6th ed. 2018).

10. See Restatement of the L. of Liab. Ins. $\$ 13 \mathrm{cmt}$ a (Am. L. Inst. 2019) (noting the four-corners, eight-corners, and complaint allegation rule terminology); William T. Barker, When Can Extrinsic Evidence Defeat the Duty to Defend?, New Appleman on Ins.: Current Critical Issues in Ins. Law, Apr. 2007, at 1-3 (referring to the exclusive pleading rule).

11. Banner Bank v. First Am. Title Ins. Co., 916 F.3d 1323, 1326-27 (10th Cir. 2019) (discussing Utah law); Lupu v. Loan City, LLC, 903 F.3d 382, 389-92 (3d Cir. 2018) (applying Pennsylvania law); Farmers Ins. Exch. v. Wessel, 477 P.3d 1101, 1105 (Mont. 2020); Bighorn Logging Corp. v. Truck Ins. Exch., 437 P.3d 287, 293 (Or. Ct. App. 2019).

12. Richards v. State Farm Lloyds, 597 S.W.3d 492, 494-95 (Tex. 2020).

13. Chavez v. Ariz. Auto. Ins. Co., 947 F.3d 642, 646 (10th Cir. 2020) (applying Colorado law); Kiely v. Phila. Contributionship Ins. Co., 206 A.3d 1140, 1146 (Pa. Super. Ct. 2019); Water Well Sols. Serv. Grp. Inc. v. Consol. Ins. Co., 881 N.W.2d 285, 294-97 (Wis. 2016).

14. JERRY \& Richmond, supra note 9, at 698. 2009).

15. CACI Int'l, Inc. v. St. Paul Fire \& Marine Ins. Co., 566 F.3d 150, 155 (4th Cir. 
quences for insurers $\ldots$. $^{16}$

Second, there is the extrinsic evidence approach. ${ }^{17}$ In comparison to the eight-corners rule, courts employing the extrinsic evidence approach hold that an insurer must look beyond the pleadings and consider any facts brought to its attention or any facts that it reasonably could discover at the time suit was filed in deciding whether it has a duty to defend. ${ }^{18}$ For courts following the extrinsic evidence approach, the allegations in the plaintiff's petition or complaint are but the starting point in analyzing the insurer's duty to defend. ${ }^{19}$ The reasoning behind the extrinsic evidence approach is straightforward: an insurer should not be able to avoid its duty to defend by ignoring facts relevant to the insured's potential liability and instead seizing on a pleading that may be inaccurate or falsified. ${ }^{20}$ The insurer's exclusive concern when analyzing its duty to defend should be "whether the judgment that may ultimately be entered against the insured might, either in whole or in part, be encompassed by the policy." 21

Standard liability insurance policies that businesses and individuals typically purchase provide that the insurance company will pay the cost of the insured's defense in addition to the policy's liability limits. ${ }^{22}$ This is a valuable benefit to the insured and a potentially significant expense for the insurer because defense costs may, and frequently do, exceed any set-

16. JERRY \& RichMOND, supra note 9, at 698-99 (footnotes omitted).

17. Id. at 699-700.

18. See, e.g., Att'ys Liab. Prot. Soc'y, Inc. v. Ingaldson Fitzgerald, P.C., 370 P.3d 1101, 1111-12 (Alaska 2016) ("[T]he duty to defend attaches, if at all, on the basis of the complaint and known or reasonably ascertainable facts at the time of the complaint."); Thornburg v. Schweitzer, 240 P.3d 969, 978 (Kan. Ct. App. 2010) (acknowledging that an "insurer must look beyond the effect of the pleadings and consider any facts brought to its attention or any facts which it could reasonably discover in determining whether it has a duty to defend"); Billings v. Com. Ins. Co., 936 N.E.2d 408, 414 (Mass. 2010) ("The duty to defend is determined based on the facts alleged in the complaint, and on facts known or readily knowable by the insurer that may aid in its interpretation of the allegations in the complaint."); Allen v. Cont'l W. Ins. Co., 436 S.W.3d 548, 553 (Mo. 2014) (“[T]he insurer's duty to defend arises only from potential coverage based on facts: (1) alleged in the petition; (2) the insurer knows at the outset of the case; or (3) that are reasonably apparent to the insurer at the outset of the case."); Merrick v. Fischer, Rounds \& Assocs., Inc., 939 N.W.2d 795, 807 (Neb. 2020) ("An insurer has a duty to defend if (1) the allegations of the complaint, if true, would obligate the insurer to indemnify, or (2) a reasonable investigation of the facts by the insurer would or does disclose facts that would obligate the insurer to indemnify."); Nat'l Sur. Corp. v. Immunex Corp., 297 P.3d 688, 691 (Wash. 2013) ("Facts that are extrinsic to the pleadings, but readily available to the insurer, may give rise to the duty [to defend].").

19. See, e.g., McMillin Homes Constr., Inc. v. Nat'l Fire \& Marine Ins. Co., 247 Cal. Rptr. 3d 825, 830 (Ct. App. 2019) ("To evaluate whether an insurer owes a duty to defend, we start by comparing the allegations of the complaint to the terms of the policy. Extrinsic facts may give rise to a duty to defend where they reveal the possibility of coverage." (citation omitted)); Sw. Steel Coil, Inc. v. Redwood Fire \& Cas. Ins. Co., 148 P.3d 806, 812 (N.M. Ct. App. 2006) ("If the duty to defend does not arise from the complaint on its face, the duty may arise if the insurer is notified of factual contentions or if the insurer could have discovered facts, through reasonable investigation, implicating a duty to defend.").

20. Allan D. Windt, 1 Insurance Claims and Disputes $\S 4: 3$ (6th ed. 2013).

21. Id. 2015).

22. Amerisure Mut. Ins. Co. v. Arch Specialty Ins. Co., 784 F.3d 270, 274 (5th Cir. 
tlement or judgment ultimately paid. ${ }^{23}$ In light of the potential expense associated with providing a defense, an insurer that has been asked to defend an insured may want to disclaim its duty to defend based on extrinsic evidence that establishes that it will ultimately have no duty to indemnify the insured. Of course, an insurer generally cannot decline to defend its insured if, in making that determination, it is limited to the facts alleged in the plaintiff's petition or complaint; after all, even in extrinsic evidence jurisdictions, it usually is the allegations in that pleading that trigger the insurer's duty to defend in the first place. ${ }^{24}$

Thus, insurers frequently explore or test their ability to rely on extrinsic evidence to deny or disclaim their duty to defend when the plaintiff's complaint or petition alleges facts that trigger the duty. In other words, if an insurer must, in many jurisdictions, consider extrinsic evidence in accepting its duty to defend, can it also rely on extrinsic evidence to deny or exit a defense? The answer, generally, is no; the use of extrinsic evidence is usually not a two-way street. ${ }^{25}$ As a result, even an insurance company

23. See Allstate Ins. Co. v. RJT Enters., Inc., 692 So. 2d 142, 145 (Fla. 1997) (stating that the cost of a defense may exceed the indemnity amount); Sherwood Brands, Inc. v. Hartford Accident \& Indem. Co., 698 A.2d 1078, 1083 (Md. 1997) (noting that the cost of defending the insured often approximates or exceeds the judgment amount).

24. See Restatement of the L. of Liab. Ins. $\S 13 \mathrm{cmt}$. b, reporters' note b (Ам. L. INST. 2019).

25. See, e.g., Selective Ins. Co. of S.C. v. Target Corp., 845 F.3d 263, 269 (7th Cir. 2016) ("When an insurer tries to deny coverage without seeking a declaratory judgment or defending under a reservation of rights, our inquiry [under Illinois law] is necessarily limited to the allegations in the underlying complaint."); Atl. Cas. Ins. Co. v. Innovative Roofing Sys., Inc., 411 F. Supp. 3d 1287, 1291 (M.D. Fla. 2019) ("In determining whether an obligation to defend exists [under Florida law], a court may not consider any evidence or testimony outside the four corners of the complaint against the insured."); ACE Am. Ins. Co. v. Ascend One Corp., 570 F. Supp. 2d 789, 795 (D. Md. 2008) (citing Aetna Cas. \& Sur. Co. v. Cochran, 651 A.2d 859, 863 (Md. 1995)); Cap. Env't Servs., Inc. v. N. River Ins. Co., 536 F. Supp. 2d 633, 642 (E.D. Va. 2008) (interpreting Virginia law); Nortek, Inc. v. Liberty Mut. Ins. Co., 858 F. Supp. 1231, 1236 (D.R.I. 1994) (applying Rhode Island law); Devine v. Great Divide Ins. Co., 350 P.3d 782, 788 (Alaska 2015) (quoting Afcan v. Mut. Fire, Marine \& Inland Ins. Co., 595 P.2d 638, 645 (Alaska 1979)); Kolbek v. Truck Ins. Exch., 431 S.W.3d 900, 907-08 (Ark. 2014) ("Generally, insurers are not allowed to refuse to defend on the grounds that they are in possession of information establishing that the allegations in the complaint giving rise to coverage are untrue."); Cotter Corp. v. Am. Empire Surplus Lines Ins. Co., 90 P.3d 814, 829 (Colo. 2004) ("[W]e base the determination of an insurer's duty to defend on the allegations contained in the underlying complaint when such insurer refuses to defend his insured.”); New London Cnty. Mut. Ins. Co. v. Sielski, 123 A.3d 925, 936 (Conn. App. Ct. 2015) ("Although there are circumstances where facts beyond those alleged in the underlying complaint and which are known to the insurer can require the insurer to provide a defense, an insurer cannot rely on extrinsic facts to refuse to provide a defense."); Penn-Am. Ins. Co. v. Disabled Am. Veterans, Inc., 481 S.E.2d 850, 852 (Ga. Ct. App. 1997) (rejecting the insurer's argument that the court should excuse its duty to defend based on extrinsic evidence); Dairy Rd. Partners v. Island Ins. Co., 992 P.2d 93, 117 (Haw. 2000) (adopting the general rule that an insurer may not use extrinsic evidence to defeat the duty to defend while, at the same time, recognizing a limited exception); Alombro v. Salman, 536 So. 2d 764, 767 (La. Ct. App. 1988) ("The insurer's duty to defend is measured by the allegations of the petition even though the insurer may have determined there was no coverage on the basis of known or ascertainable fact."); Penney v. Capitol City Transfer, Inc., 707 A.2d 387, 389 (Me. 1998) ("Even though evidence beyond the pleadings may later establish the absence of a duty to indemnify, that evidence is not properly considered in determining the duty to defend."); Century Sur. Co. v. Andrew, 432 P.3d 
with a solid factual defense to coverage generally must defend the insured under a reservation of rights and file a separate declaratory judgment action to establish that it will have no duty to indemnify the insured and can therefore terminate its duty to defend. ${ }^{26}$ "Only in a declaratory-judgment action filed while the insurer is defending, or in a coverage action that takes place after the insurer has fulfilled the duty to defend, may the insurer use facts outside the complaint as the basis for avoiding coverage." 27 From an insurer's perspective, however, that approach is of limited value unless the declaratory judgment action can be decided before the tort action against the insured concludes. ${ }^{28}$ In fact, such an outcome is rare. ${ }^{29}$ Even if the insurer may apply to intervene in the tort action to seek a stay of that litigation until the declaratory judgment action is resolved, the trial court hearing the tort action has the discretion to deny a stay. ${ }^{30}$ For that matter, "[j]udges are often reluctant to put the tort action on hold because they do not want to delay the injured party's possible recovery." 31 Consequently, an insurer may be forced to shoulder the expense of defending a lawsuit alleging uncovered claims or causes of action well after it has discovered that it will never have to indemnify the insured.

Although the general rule holds that an insurer may not rely on extrinsic evidence to refuse to defend an insured, some courts that adhere to the general rule occasionally recognize exceptions. ${ }^{32}$ Plus, there is a con-

180, 184 n.4 (Nev. 2018) ("[A]s a general rule, facts outside of the complaint cannot justify an insurer's refusal to defend its insured."); W9/PHC Real Est. LP v. Farm Fam. Cas. Ins. Co., 970 A.2d 382, 391 (N.J. Super. Ct. App. Div. 2009) ("[A]n insurer must defend if the complaint states a cause of action covered by the policy even if the insurer knows of extrinsic facts which would put the claim outside of the insurance coverage."); Found. Rsrv. Ins. Co. v. Mullenix, 642 P.2d 604, 606 (N.M. 1982) ("[T]he complaint filed in this case alleges facts within the coverage of the policy, and it is the duty of the insurer to undertake the defense even though its own investigation has revealed that the claim sued upon is not in fact covered.”); One Reason Rd., LLC v. Seneca Ins. Co., 83 N.Y.S.3d 235, 238 (App. Div. 2018) (quoting Fitzpatrick v. Am. Honda Motor Co., 575 N.E.2d 90, 91-92 (N.Y. 1991)); De Smet Farm Mut. Ins. Co. v. Gulbranson Dev. Co., 779 N.W.2d 148, 155-56 (S.D. 2010) ("Even when extraneous facts available in depositions and other record evidence outside the pleadings show the claim as pleaded in the underlying action is false, groundless, or even fraudulent, the duty to defend cannot be defeated if on the face of the pleadings it indicates the claim falls within the policy coverage.”); Webb v. USAA Cas. Ins. Co., 457 P.3d 1258, 1265 (Wash. Ct. App. 2020) ("An insurer can consider facts outside of the complaint only to find a duty to defend, not to deny a duty to defend.").

26. Restatement of the L. of Liab. Ins. $§ 13 \mathrm{cmt}$. c.

27. $I d$.

28. Barker, supra note 10 , at 6.

29. See Jerry \& Richmond, supra note 9, at 709 ("Although, in theory, an insurer may be entitled to seek a stay of the underlying tort litigation until the declaratory judgment action is resolved, in practice, this is rarely an avenue of relief for insurers.").

30. Augspurger v. MFA Oil Co., 940 S.W.2d 934, 936 (Mo. Ct. App. 1997); Lodigensky v. Am. States Preferred Ins. Co., 898 S.W.2d 661, 667 (Mo. Ct. App. 1995).

31. JERRY \& RICHMOND, supra note 9, at 709.

32. See, e.g., BBG Design Build, LLC v. S. Owners Ins. Co., 820 F. App'x 962, 965-66 (11th Cir. 2020) (applying Florida law and applying an equitable exception to the eightcorners rule which holds that a court may consider undisputed extrinsic facts, which, had they been alleged in the complaint, clearly would have defeated coverage); Pompa v. Am. Fam. Mut. Ins. Co., 520 F.3d 1139, 1147 (10th Cir. 2008) (predicting Colorado law in a case 
trary minority rule. ${ }^{33}$ It is therefore fair to ask whether an insurer should be allowed to rely on extrinsic evidence to disclaim or extinguish its duty to defend when the plaintiff's complaint or petition alleges facts that implicate coverage and, if so, under what circumstances. This question is timely. First, two 2020 Texas Supreme Court decisions address this question and offer different answers based on the facts presented: Richards $v$. State Farm Lloyds ${ }^{34}$ and Loya Insurance Co. v. Avalos. ${ }^{35}$ Second, as Richards and Loya demonstrate, insurers' use of extrinsic evidence to excuse their defense obligations, at least in some situations, is an ongoing litigation strategy. That is not to say that the strategy is good or bad, or wise or imprudent, but it is to say that the extrinsic evidence issue will continue to surface in key cases in various jurisdictions. Third, while insurers' use of extrinsic evidence to defeat the duty to defend is hotly contested by policyholders, courts that have considered the issue over the years have rarely discussed it in a meaningful fashion in their opinions. ${ }^{36}$ The resulting lack of guidance hampers courts either confronting the issue for the first time or entertaining reconsideration of prior holdings.

Looking ahead, Part II of this Article discusses the Richards and Avalos decisions and their broader implications for the use of extrinsic evidence in excusing insurers' duty to defend. Part II refutes the argument raised by the insurer in Richards that the eight-corners rule should control an insurer's duty to defend only where the policy provides that the insurer will defend the insured even if the third-party's suit is groundless, false, or fraudulent, thus permitting the use of extrinsic evidence to excuse an insurer's duty to defend where its policy omits that language. ${ }^{37}$

where the insured's criminal conviction was "an indisputable fact that [was] not an element of either the cause of action or a defense in the underlying litigation"); Dairy Rd. Partners v. Island Ins. Co., 992 P.2d 93, 117 (Haw. 2000) (“[An] insurer may only disclaim its duty to defend by showing that none of the facts upon which it relies [to deny a defense] might be resolved differently in the underlying lawsuit."); Polarome Int'l, Inc. v. Greenwich Ins. Co., 961 A.2d 29, 50 (N.J. Super. Ct. App. Div. 2008) (permitting the insurers to consider extrinsic evidence where the complaints were ambiguous, and the insurers were unable to evaluate their potential duties to indemnify the insured and thus their duties to defend).

33. See, e.g., Alfa Mut. Ins. Co. v. Jones, 555 So. 2d 77, 77-79 (Ala. 1989) (examining a stipulation in addition to the plaintiff's complaint in determining that the insurer owed no duty to defend); Teufel v. Am. Fam. Mut. Ins. Co., 419 P.3d 546, 549 (Ariz. 2018) ("The insurer may investigate the matter, however, and refuse to defend based on facts discovered outside the complaint that take the case outside coverage.”); Riddell, Inc. v. Superior Ct., 222 Cal. Rptr. 3d 384, 391 (Ct. App. 2017) ("Extrinsic facts can also negate the duty to defend, but only if the facts are undisputed and conclusively eliminate the potential for coverage.”); Gonzalez v. Fire Ins. Exch., 184 Cal. Rptr. 3d 394, 409 (Ct. App. 2015) ("Extrinsic facts negating an insurer's duty to defend must have been known to the insurer at the time of tender or at the inception of the lawsuit."); 5200 Keystone Ltd. Realty, LLC v. Neth. Ins. Co., 29 N.E.3d 156, 161 (Ind. Ct. App. 2015) ("If an insurer is aware of facts outside the pleadings that clearly disclose an absence of coverage, it can refuse to defend."); Haarstad v. Graff, 517 N.W.2d 582, 585 (Minn. 1994) ("Because State Farm in this case had sufficient knowledge of Graff's intentional acts independent of the allegations in the complaint, we hold State Farm had no duty to defend in this case.").

34. 597 S.W.3d 492 (Tex. 2020).

35. 610 S.W.3d 878 (Tex. 2020).

36. Barker, supra note 10 , at 2 .

37. Richards, 597 S.W.3d at 497-98. 
Part III examines the general principles that have developed around insurers' use of extrinsic evidence to excuse their duty to defend. After sketching those principles or rules, this Part asserts that an insurer should be allowed to rely on extrinsic evidence that relates solely to the issue of coverage to excuse its duty to defend, notwithstanding the facts alleged in the plaintiff's pleadings. Furthermore, an insurer should be allowed to use extrinsic evidence to excuse its duty to defend even if the evidence arguably relates in whole or in part to the merits of the plaintiff's allegations against the insured where the evidence is incontrovertible. Examples of cases involving this latter category of evidence include those in which the insured has been convicted of a crime that establishes the intent to cause harm and those in which the insured has been convicted of a crime that triggers a criminal act, criminal conviction, or illegal act exclusion in the insurance policy at issue. ${ }^{38}$

\section{THE TEXAS CASES AND THEIR BROADER IMPLICATIONS}

The Texas Supreme Court has historically adhered to the eight-corners rule when determining an insurer's duty to defend. ${ }^{39}$ This has been true regardless of whether the insured or the insurer advocated for the use of such evidence. ${ }^{40}$ Before 2020, the court had signaled that perhaps it would be willing to consider extrinsic evidence that defeated an insurer's duty to defend, but it found reasons not to do so in the cases then at hand. ${ }^{41}$ Then, in 2020, the court was presented with two extrinsic evidence cases in close order: Richards v. State Farm Lloyds ${ }^{42}$ and Loya Insurance Co. v. Avalos. ${ }^{43}$ In Richards, the court rejected the use of extrinsic evidence to extinguish an insurer's duty to defend, ${ }^{44}$ while in Avalos it held the opposite. ${ }^{45}$ 2008).

38. See Secura Supreme Ins. Co. v. M.S.M., 755 N.W.2d 320, 325 (Minn. Ct. App.

39. See, e.g., Pine Oak Builders, Inc. v. Great Am. Lloyds Ins. Co., 279 S.W.3d 650, 655 (Tex. 2009) ("In deciding the duty to defend, the court should not consider extrinsic evidence from either the insurer or the insured that contradicts the allegations of the underlying petition.").

40. Id.

41. See, e.g., Zurich Am. Ins. Co. v. Nokia, Inc., 268 S.W.3d 487, 498 (Tex. 2008) ("Thus, even if we were to recognize this exception to the eight-corners rule [allowing extrinsic evidence going solely to a fundamental issue of coverage when a pleading is vague], this case would not fit within its parameters. Accordingly, we decline to do so."); GuideOne Elite Ins. Co. v. Fielder Rd. Baptist Church, 197 S.W.3d 305, 308-11 (Tex. 2006) (rejecting a proposed exception to the eight-corners rule because it would conflate the insurer's duties to defend and indemnify).

42. 597 S.W.3d 492.

43. 610 S.W.3d 878 (Tex. 2020).

44. Richards, 597 S.W.3d at 500 .

45. Avalos, 610 S.W.3d at 884. 


\section{A. The Effect of "Groundless, False, or Fraudulent" Language Qualifying the Duty to Defend}

\section{The Richards Case}

Richards arose out of an all-terrain vehicle (ATV) accident in which a little boy, Jayden Meals, was killed. ${ }^{46}$ At the time of the accident, Jayden was in the care of his paternal grandparents, Janet and Melvin Richards. ${ }^{47}$ Jayden's mother, Amanda Meals, sued her in-laws for her son's death, alleging that they negligently failed to supervise and educate him on riding the ATV. ${ }^{48}$ She alleged that the accident occurred "[o]n or near" the Richards's home. ${ }^{49}$

The Richards were insured under a State Farm Lloyds (State Farm) homeowner's policy, which provided that "[i]f a claim [was] made or a suit [was] brought against an insured for damages because of bodily injury or property damage" covered by the policy, State Farm would pay up to its policy limit in indemnity and "provide a defense at [its] expense by counsel of [its] choice." 50 State Farm agreed to defend the Richards under a reservation of rights. ${ }^{51}$ State Farm then filed a declaratory judgment action in the U.S. District Court for the Northern District of Texas, seeking a declaration that it had no duty to defend or indemnify the Richards in connection with their daughter-in-law's suit. ${ }^{52}$

State Farm moved for summary judgment on the basis that the "motorvehicle exclusion" and the "insured exclusion" in its policy precluded coverage. ${ }^{53}$ Under the State Farm policy, "[a]n ATV used "while off an insured location' [was] a 'motor vehicle" " within the meaning of the motorvehicle exclusion. ${ }^{54}$ State Farm contended that the exclusion applied because, at the time of the accident, Jayden was riding the ATV on a public

\footnotetext{
46. Richards, 597 S.W.3d at 495.

47. Id.

48. Id.

49. Id. (alteration in original).

50. Id.

51. Id. To explain, an insurer that defends under a reservation of rights agrees to defend the insured while preserving its ability to later dispute coverage. See Hoover v. Maxum Indem. Co., 730 S.E.2d 413, 416 (Ga. 2012) ("A reservation of rights is . . . designed to allow an insurer to provide a defense to its insured while still preserving the option of litigating and ultimately denying coverage."); Becker v. Bar Plan Mut. Ins. Co., 429 P.3d 212, 217 (Kan. 2018) ("Under Kansas law, the reservation of rights rule allows an insurer to assume a defense of an insured without waiving noncoverage defenses by issuing a timely notice to that person, reserving the right to question coverage and assert policy defenses.”); Mastellone v. Lightning Rod Mut. Ins. Co., 884 N.E.2d 1130, 1139-40 (Ohio Ct. App. 2008) ("By definition, a reservation of rights means that the insurer does not believe that coverage is available under the policy, but that it is proceeding to defend a claim in order to control the defense.”); Harleysville Grp. Ins. v. Heritage Cmtys., Inc., 803 S.E.2d 288, 297 (S.C. 2017) ("A reservation of rights is a way for an insurer to avoid breaching its duty to defend and seek to suspend operation of the doctrines of waiver and estoppel prior to a determination of the insured's liability."). An insurer that defends under a reservation of rights must defend the insured just as competently and diligently as it would have otherwise.

52. Richards, 597 S.W.3d at 495.

53. Id.

54. Id. (quoting the State Farm policy).
} 
trail rather than on his grandparents' property. ${ }^{55}$ To prove where the accident occurred, State Farm submitted a copy of the responding police department's vehicle crash report, which gave the accident's location. ${ }^{56}$

The insured exclusion precluded coverage for insureds' bodily injuries and "define[d] 'insured' to include 'you and, if residents of your household ... your relatives; and ... any other person under the age of 21 who is in the care of a person described above." 57 According to State Farm, "Jayden was an 'insured' because the grandparents were his joint managing conservators. As proof, State Farm submitted a court order from a suit affecting the parent-child relationship (SAPCR)."58

The Richards countered that under the eight-corners rule, the district court could not consider the crash report or the SAPCR order in deciding whether State Farm owed them a defense. ${ }^{59}$ The district court disagreed. ${ }^{60}$ The district court explained that the State Farm policy issued to the Richards did not require State Farm "to defend 'all actions against its insured no matter if the allegations of the suit are groundless, false or fraudulent." "61 Rather, State Farm's duty to defend arose "only if suit [was] brought to which the coverage applie[d]." 62 As a result, the eightcorners rule did not control the analysis and the court could consider extrinsic evidence in evaluating State Farm's duty to defend. ${ }^{63}$ The district court had previously articulated this position in B. Hall Contracting Inc. v. Evanston Insurance Co. ${ }^{64}$

Based on the extrinsic evidence that State Farm submitted, the district court determined that State Farm had no duty to defend or indemnify the Richards. ${ }^{65}$ The court therefore granted State Farm's summary judgment motion. ${ }^{66}$ The Richards appealed to the Fifth Circuit, which certified the following question to the Texas Supreme Court: "Is the policy-language exception to the eight-corners rule articulated in B. Hall Contracting ... a permissible exception under Texas law?"67

In answering the certified question, the Richards court began by noting that parties to an insurance contract could replace default rules of construction-such as the eight-corners rule-with agreed rules of construc-

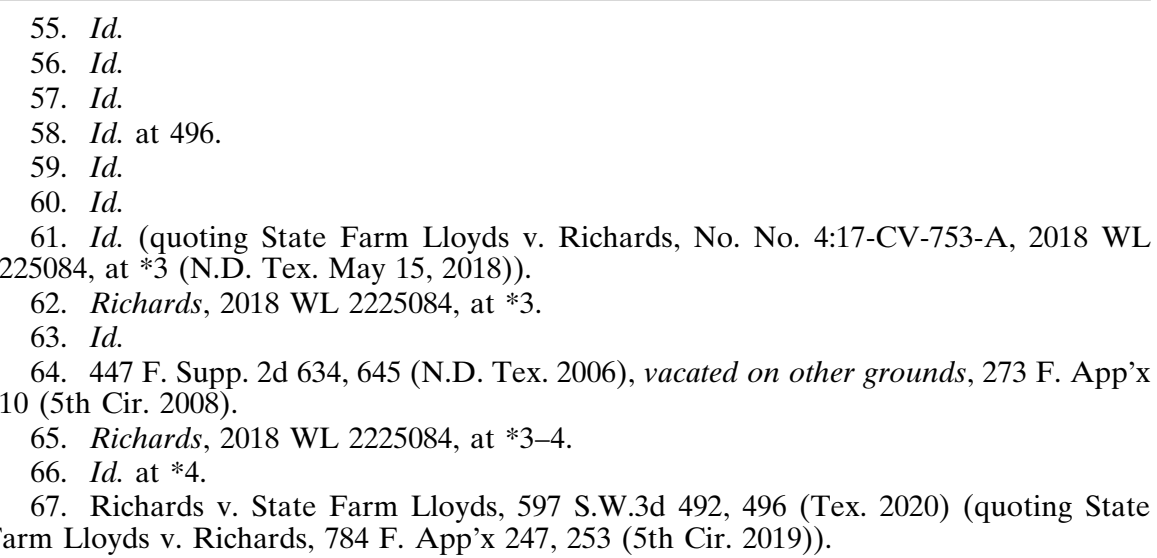


tion. ${ }^{68}$ "Thus, if an insurance policy contained language inconsistent with the eight-corners rule, the policy language would control." 69 The question here, however, was not whether the parties had affirmatively contracted around the eight-corners rule as they might have, but whether they had effectively done so "by declining to expressly agree that State Farm must defend claims "even if groundless, false or fraudulent."70

State Farm took the position that courts created the eight-corners rule to enforce groundless-claims clauses, which were once routine in liability insurance policies. ${ }^{71}$ By extension, then, the eight-corners rule should govern insurers' duty to defend only with respect to insurance policies containing the same or similar language, which is less common in newer policies. ${ }^{72}$ State Farm argued that "[b]ecause the circumstances giving rise to the eight-corners rule (the language commonly used in insurance policies) have changed, ... the eight-corners rule itself must change, no matter how deeply embedded in the law it has become."73 The Richards, on the other hand, argued that Texas courts' application of the eight-corners rule had never pivoted on the existence of a groundless-claims clause. ${ }^{74}$ In support of this argument, they cited Texas Court of Appeals cases where the court applied the eight-corners rule despite the lack of groundless-claims clauses in the policies at issue. ${ }^{75}$ "Because the presence or absence of a groundless-claims clause ha[d] rarely, if ever, been important to Texas courts' analysis of the contractual duty to defend, and because Texas courts routinely appl[ied] the eight-corners rule without looking for a groundless-claims clause," the Richards argued that the court was compelled to hold "that the federal district court's 'policy-language exception'" to the eight-corners rule misconstrued Texas law. ${ }^{76}$

The Texas Supreme Court sided with the Richards, stating that "State Farm did not contract away the eight-corners rule altogether merely by omitting from its policy an express agreement to defend claims that are 'groundless, false or fraudulent." "77 The Richards court explained that it had adopted the eight-corners rule in 1956 and had applied it faithfully

68. Id. at 497. Whether the Texas Supreme Court's view of the eight-corners rule as a matter of contract construction or interpretation is correct is unclear, although at least one other court has suggested a similar approach. Loftin v. U.S. Fire Ins. Co., 127 S.E.2d 53, 58 (Ga. Ct. App. 1962). In contrast, Section 13 of the Restatement of the Law of Liability Insurance treats the eight-corners rule as a substantive rule of law. See Restatement of THE L. Of Liab. Ins. $\S 13 \mathrm{cmt}$. a (Ам. L. Inst. 2019). As a practical matter, standard insurance policies do not provide how the insurer's duty to defend will be determined.

69. Richards, 597 S.W.3d at 497.

70. Id.

71. Id. at 497-98.

72. Id. at 498 .

73. Id.

74. $I d$.

75. Id. (first citing Pine Oak Builders, Inc. v. Great Am. Lloyds Ins. Co., 292 S.W.3d 48, 52 (Tex. App.-Houston [14th. Dist.] 2006), aff'd in part, rev'd in part on other grounds, 279 S.W.3d 650 (Tex. 2009); then citing King v. Dall. Fire Ins. Co., 27 S.W.3d 117, 121 (Tex. App.-Houston [1st Dist.] 2000), rev'd on other grounds, 85 S.W.3d 185 (Tex. 2002)).

76. $I d$.

77. $I d$. 
ever since. ${ }^{78}$ In repeatedly affirming the rule, the court had never rested its application on the presence of groundless-claims language in the subject policy. ${ }^{79}$ The Texas Court of Appeals had taken the same approach. ${ }^{80}$ Given Texas courts' rigid adherence to the eight-corners rule, the Richards court reasoned, insurance companies had to know that courts applying Texas law would apply the rule, and it was therefore safe to presume that they drafted their policies with the eight-corners rule in mind. ${ }^{81}$ Here:

State Farm agreed to defend the policyholders if "a claim is made or a suit is brought against an insured for damages because of bodily injury . . . to which this coverage applies." To determine whether such a "claim" has been "made" or a "suit" has been "brought," courts naturally look first to the claims made, to the suit brought. If the claim is "for damages because of bodily injury ... to which coverage applies," the duty to defend is implicated. The eight-corners rule merely acknowledges that, under many common duty-to-defend clauses, only the petition and the policy are relevant to the initial inquiry into whether the petition's claim fits within the policy's coverage. This is how Texas courts have long interpreted contractual duties to defend. If any party is familiar with the overwhelming precedent to that effect, it is a large insurance company. State Farm makes good-faith arguments for its position, but it is well aware of the courts' longstanding interpretive approach to contractual duties to defend, and it knows how to contract around that approach. It did not do so merely by omitting the words "groundless, false or fraudulent," . . . from this policy. 82

The Richards court acknowledged that it is common for a complaint or petition to plead a claim that could trigger the duty to defend but omit facts necessary for the insurer to evaluate its duty to indemnify the insured. ${ }^{83}$ In such cases, some courts applying Texas law have considered "extrinsic evidence on coverage issues that do not overlap with the merits to determine whether" the plaintiff is seeking covered damages. ${ }^{84}$ But

78. Id. (quoting Heyden Newport Chem. Corp. v. S. Gen. Ins. Co., 387 S.W.2d 22, 24 (Tex. 1965)).

79. $I d$.

80. Id. at 499 .

81. Id. This statement is consistent with the court's earlier statement that the eightcorners rule is a default rule of contract construction or interpretation rather than a substantive rule of law. Id. at 497.

82. Id. at 500 (first and second alteration in original).

83. Id.

84. Id. (citing State Farm Lloyds v. Richards, 784 F. App'x 247, 250-51 (5th Cir. 2019); then citing Ooida Risk Retention Grp., Inc. v. Williams, 579 F.3d 469, 476 (5th Cir. 2009); and then citing Tex. Pol. Subdivisions Prop./Cas. Joint Self Ins. Fund v. Pharr-San JuanAlamo ISD, No. 13-17-00655-CV, 2019 WL 4678433, at *5 (Tex. App.-Corpus Christi-Edinburg Sept. 26, 2019, no pet.) (mem. op.)); see also Northfield Ins. Co. v. Loving Home Care, Inc., 363 F.3d 523, 531 (5th Cir. 2004) (predicting that the only circumstance in which the Texas Supreme Court might deviate from the eight-corners rule would be "when it is initially impossible to discern whether coverage is potentially implicated and when the extrinsic evidence goes solely to a fundamental issue of coverage which does not overlap with the merits of or engage the truth or falsity of any facts alleged in the underly- 
because the Fifth Circuit had not asked about that practice, the Richards court did not opine on it. ${ }^{85}$ The court also declined to consider "whether [different] policy language or other factual scenarios [might] justify the use of extrinsic evidence to determine" an insurer's duty to defend on the theory that the possible scenarios out of which arguments for weighing such evidence could arise exceeded imagination. ${ }^{86}$ At bottom, the court held "only that the 'policy-language exception' to the eight-corners rule" framed in B. Hall Contracting and enforced against the Richards, which links the eight-corners rule solely to liability insurance policies that contain a groundless-claims clause, was "not a permissible exception under Texas law." 87

Once back in the Fifth Circuit, State Farm, now without its preferred eight-corners rule argument, contended that the court should nonetheless permit the use of extrinsic evidence to excuse its duty to defend under a "very narrow' exception" to the eight-corners rule that the court had previously recognized. ${ }^{88}$ That exception allows the use of extrinsic evidence "where it is initially impossible to discern whether coverage is potentially implicated and when the extrinsic evidence goes solely to a fundamental issue of coverage which does not overlap with the merits of or engage the truth or falsity of any facts alleged in the underlying case." 89 The court, however, reasoned that this exception did not apply insofar as the motor-vehicle exclusion was concerned:

In Meals's third-amended complaint, she alleges "Jayden was killed because" "[the Richards] allowed Jayden to operate the ATV on their property." Meals's allegations of negligence focus on acts or omissions on the Richards' property. For example, Meals alleges the Richards were negligent for "[f]ailing to directly supervise a person younger than 14 years of age operating an ATV on the Richards' property in violation of Texas Transportation Code § 663.032"; "[f]ailing to monitor Jayden on the Richards' property as a person using ordinary care would have done in the same or similar circumstances"; allowing Jayden to operate the ATV on the Richards' property without a helmet, other protective gear, seatbelt, proper instruction, or a certified training course; "[f]ailing to inspect the ATV before allowing Jayden to operate the vehicle on the Richards' property to ensure that it was safe"; and "[a]llowing Jayden to oper-

ing case”); Zurich Am. Ins. Co. v. Nokia, Inc., 268 S.W.3d 487, 497-98 (Tex. 2008) (hinting that the court might someday adopt the Northfield test, but declining to do so based on the facts); GuideOne Elite Ins. Co. v. Fielder Rd. Baptist Church, 197 S.W.3d 305, 308 (Tex. 2006) ("Although this Court has never expressly recognized an exception to the eightcorners rule, other courts have. Generally, these courts have drawn a very narrow exception, permitting the use of extrinsic evidence only when relevant to an independent and discrete coverage issue, not touching on the merits of the underlying third-party claim.").

85. Richards, 597 S.W.3d at 500.

86. Id.

87. $I d$.

88. State Farm Lloyds v. Richards, 966 F.3d 389, 394 (5th Cir. 2020) (quoting GuideOne Specialty Mut. Ins. Co. v. Missionary Church of Disciples of Jesus Christ, 687 F.3d 676, 686 (5th Cir. 2012))

89. Id. (quoting Ooida, 579 F.3d at 475). 
ate the ATV on the Richards' property without the skills, abilities, or judgment needed to operate the ATV safely."

Considering these allegations, the extrinsic evidence State Farm seeks to admit problematically "overlap[s] with the merits of or engage[s] the truth or falsity of [] facts alleged in the underlying case." By arguing that only the location of the "accident" ... matters, State Farm is challenging Meals's claim that "Jayden was killed because of Janet Richards allowing him to operate the ATV on their property." In other words, the extrinsic evidence State Farm urges the court to consider is simply too entwined in the merits for the "very narrow exception" to apply. This type of "overlapping evidence" "poses a significant risk of undermining the insured's ability to defend itself in the underlying litigation." 90

State Farm also argued that it should be permitted to introduce extrinsic evidence implicating the insured exclusion in its policy, but the Fifth Circuit panel concluded that the very narrow exception State Farm hoped to invoke did not apply here either. ${ }^{91}$ Again, the extrinsic evidence State Farm wanted to admit called into question the truth or falsity of the facts alleged by the plaintiff:

Specifically, State Farm seeks to introduce the Richards' admission that they were Jayden's grandparents, as well as a court order appointing them as joint-managing conservators to show that Jayden was a "resident of [the Richards'] household." . . .

Here, the policy lists the Richards as the named insureds. And, under the policy, all other subcategories of "insureds" must be "residents of" the Richards' household. Meals's third-amended complaint does not contain any allegations suggesting Jayden was a "resident" of the Richards' household. Rather, the complaint states that "Jayden resided with his Mother and [maternal] Grandmother, Sharon Culver, at 727 Jones Road, Weatherford, Parker County, Texas, where he had resided for years." So considering the extrinsic evidence to determine whether Jayden was a "resident of [the Richards'] household," would impermissibly "engage the truth or falsity of [ ] facts alleged in the underlying case." 92

In short, the eight-corners rule controlled the analysis, and the plaintiff's complaint alleged facts that potentially implicated State Farm's duty to indemnify the Richards. ${ }^{93}$ Consequently, the Fifth Circuit reversed the district court's decision holding that State Farm had no duty to defend its insureds. ${ }^{94}$

90. Id. at 395-96 (first through eighth alterations in original) (citations omitted) (first quoting Ooida, 579 F.3d at 475; then quoting GuideOne Specialty, 687 F.3d at 686; and then quoting GuideOne Elite Ins. Co. v. Fielder Rd. Baptist Church, 197 S.W.3d 305, 309 (Tex. 2006)).

91. Id. at 396

92. Id. (alteration in original) (quoting Ooida, 579 F.3d at 476).

93. Id.

94. Id. at 397. 


\section{Analyzing Groundless-Claims Clauses More Broadly}

Returning now to the Texas Supreme Court's opinion, State Farm's argument-that the eight-corners rule should control an insurer's duty to defend only where the policy provides that the insurer will defend the insured even if a third-party's lawsuit "is groundless, false or fraudulent" - warrants analysis. ${ }^{95}$ In fact, the argument merits rejection because it misapprehends the language of a policy's insuring agreement and risks blending or confusing insurers' duties to defend and indemnify.

The phrase "groundless, false, or fraudulent" in a liability insurance policy's insuring agreement or other provision promising a defense "refers to the quality of the factual and legal allegations against the insured on which the insured's liability to the plaintiff is said to rest." 96 In other words, an insurance company must defend an insured in a lawsuit in which the plaintiff's claims are wholly without merit or are asserted for some improper purpose provided that the plaintiff's complaint or petition alleges facts that, if proven, would obligate the insurer to indemnify the insured. ${ }^{97}$ Insurers originally included "groundless, false, or fraudulent" language in their policies to clarify for insureds the breadth of the duty to defend and, as part and parcel of that effort, to highlight the difference between the duty to defend and the duty to indemnify. ${ }^{98}$ Of course, the

95. Like the Texas Supreme Court in Richards, this Article will generally describe insurance policy language stating that the insurer will defend the insured even if the thirdparty's lawsuit is a groundless, false, or fraudulent as a groundless-claims clause. See Richards v. State Farm Lloyds, 597 S.W.3d 492, 497-98, 500 (Tex. 2020) (referring to groundless-claims clauses).

96. JERRY \& RichMOND, supra note 9, at 691-92 n.63.

97. Id. at 694 .

98. See generally Hartford Accident \& Indem. Co. v. Capitol Home Improvement Co., 205 A.2d 192, 195 (Conn. Cir. Ct. 1964) ("The obligation of the [insurer] to defend does not depend on whether the injured party will successfully maintain a cause of action. The policy requires the [insurer] to defend irrespective of the ultimate outcome."); Brodek v. Indem. Ins. Co. of N. Am., 11 N.E.2d 228, 237 (Ill. App. Ct. 1937) ("What is meant by the requirement that the insurer undertakes to defend the suit whether 'groundless, false or fraudulent'? If a plaintiff alleges in his pleadings that he is entitled to recover upon a ground of liability covered by the policy, then of course the defendant's insurance carrier must defend the suit; it cannot avoid that duty by determining upon its own investigation that the ground of liability alleged cannot be substantiated."); Danek v. Hommer, 100 A.2d 198, 203 (N.J. Super. Ct. App. Div. 1953) ("[T] he duty [to defend] is not abrogated by the fact that the cause of action stated cannot be maintained against the insured either in law or in fact-in other words, because the cause is groundless, false or fraudulent. Liability of the insured to the plaintiff is not the criterion; it is the allegation in the complaint of a cause of action which, if sustained, will impose a liability covered by the policy."); Zeitz v. Zurich Gen. Accident \& Liab. Ins. Co., 67 A.2d 742, 746 (Pa. Super. Ct. 1949) (discussing the breadth of the insurer's duty to defend under a policy with a groundless-claims clause); Prashker v. U.S. Guarantee Co., 144 N.Y.S.2d 451, 455 (Sup. Ct. 1955) (describing the phrase "groundless, false or fraudulent" as a "clear and explicit" expression of the insurer's broad duty to defend); see also Craig F. Stanovich, The Duty to Defend-Groundless, False, or Fraudulent, IRMI (Dec. 2014), https://www.irmi.com/articles/expert-commentary/ the-duty-to-defend-groundless-false-or-fraudulent [https://perma.cc/VWN6-JH3J] (discussing the 1973 standard CGL policy form, which included "groundless, false or fraudulent" language, and explaining how that language clarified the breadth of the insurer's duty to defend and prevented insurers from unilaterally and improperly tying it to their duty to indemnify). 
broad duty to defend that insurers once signaled by inserting groundlessclaims clauses in their policies is the same duty that an insurer has under a policy that simply obligates it to defend any suit seeking the specified covered damages. ${ }^{99}$

Compare, for example, the language of a former version of the commercial general liability (CGL) insurance policy with the current version. The former version of the CGL policy provided in pertinent part:

The company will pay on behalf of the insured all sums which the insured shall become legally obligated to pay as damages because of

Coverage A bodily injury or

Coverage $\mathrm{B}$ property damage

to which this insurance applies, caused by an occurrence, and the company shall have the right and duty to defend any suit against the insured seeking damages on account of such bodily injury or property damage, even if any of the allegations of the suit are groundless, false, or fraudulent. . . . 100

The current version of the CGL policy states:

We will pay those sums that the insured becomes legally obligated to pay as damages because of "bodily injury" or "property damage" to which this insurance applies. We will have the right and duty to defend the insured against any "suit" seeking those damages. However, we will have no duty to defend the insured against any "suit" seeking damages for "bodily injury" or "property damage" to which this insurance does not apply. ${ }^{101}$

Under the former version of the CGL policy, the insurer promised to "defend any suit against the insured seeking damages on account of bodily injury or property damage" to which the policy applied. ${ }^{102}$ Under the current version of the CGL policy, the insurer must "defend the insured against any suit seeking" "damages because of 'bodily injury' or 'property damage' to which [its] policy applies." 103 The promise to defend any suit seeking covered damages as used in the current CGL policy is the same promise made in the former version of the CGL policy and necessarily includes groundless, false, or fraudulent suits; the "groundless, false, or fraudulent" language in the former version of the CGL policy was redun-

99. See Hanover Ins. Co. v. Anova Food, LLC, 173 F. Supp. 3d 1008, 1020 (D. Haw. 2016) ("The insurer's duty to defend exists even if the facts alleged are untrue or the legal theories unsound."); Holyoke Mut. Ins. Co. v. Vibram USA, Inc., 106 N.E.3d 572, 576 (Mass. 2018) (stating that an insurer may have a duty to defend "notwithstanding the possibility that the underlying claim may ultimately fail, or that the merits of the claim are weak or frivolous").

100. Willets Point Contracting Corp. v. Hartford Ins. Grp., 429 N.Y.S.2d 230, 231 (App. Div. 1980) (emphasis added) (quoting the Hartford CGL policy at issue); see Brief for Cooper \& Scully, P.C. as Amicus Curiae at 6-7, State Farm Lloyds v. Richards, 597 S.W.3d 492 (Tex. 2020) (No. 19-0802), 2020 WL 264723 (referring to the "pre-1986 version" of the standard CGL policy when quoting the identical language and citing the 1973 version of the standard CGL policy form).

101. CGL Coverage Form, supra note 2, at 1 (emphasis added).

102. Willets Point, 429 N.Y.S.2d at 231 (emphasis added).

103. CGL Coverage Form, supra note 2, at 1 (emphasis added). 
dant. ${ }^{104}$ Indeed, when it revised the CGL policy form in 1986, the Insurance Services Office (ISO) deleted the "groundless, false or fraudulent" language for that reason. ${ }^{105}$ Where such language appears in other liability insurance policies still in circulation, it is equally redundant. ${ }^{106}$ Awkwardly, some courts continue to use the phrase in their discussion of insurers' duty to defend to highlight the breadth of the duty regardless of whether the policies they are referring to include that language. ${ }^{107}$

At least one court has reasoned that " $[\mathrm{t}]$ he purpose of [a] provision in [a] policy providing for a defense even if the suit is groundless, false or fraudulent, is to guarantee that the purchaser of a policy of liability insurance will be protected from all expense." 108 Accepting that position as true, the "groundless, false, or fraudulent" language remains redundant. This is because standard liability insurance policies with no groundlessclaims clause promise that the insurer will pay the cost of the insured's defense in addition to the policy limits. ${ }^{109}$

Furthermore, to hold that an insurance policy that obligates the insurer to defend any suit seeking covered damages warrants a different standard for determining the duty to defend as compared to a policy that illuminates the breadth of the insurer's duty to defend by incorporating groundless, false, or fraudulent suits risks blending or confusing the insurer's duties to defend and indemnify. Remember the contrast between the two duties: an insurer's duty to defend arises at the outset of the litigation and attaches where there is merely the potential for coverage. ${ }^{110}$ An insurer's duty to indemnify, on the other hand, does not come into

104. Jerry Trupin, Something You'll Want to Tell Your Insureds; One New Development; and Two Points I've Overlooked, Ins. Advoc. (Mar. 31, 2011), https://www.insurance-advocate.com/2011/03/31/something-youll-want-to-tell-your-insureds-one-new-developmentand-two-points-ive-overlooked/ [https://perma.cc/8F5E-KY3T] (explaining that "groundless, false or fraudulent" language was used in policies for years, but that in 1986, when ISO began simplifying standard policy language, the phrase was dropped from the CGL insuring agreement as redundant because "[t]he consensus was that the policy covered such claims even in the absence of [those] specific words" based on the promise to defend any suit seeking covered damages).

105. Id.

106. See Homeowners 3-Special Form, supra note 2, at 17 ("If $a$. . suit is brought against an 'insured' for damages because of 'bodily injury' or 'property damage' caused by an 'occurrence' to which this coverage applies, we will: ... . [p] ay up to our limit of liability for the damages for which an 'insured' is legally liable . . . . and . . [p]rovide a defense ... even if the suit is groundless, false or fraudulent ...." (emphasis added)). A suit necessarily encompasses a groundless, false, or fraudulent suit.

107. See, e.g., Gen. Agents Ins. Co. of Am., Inc. v. Midwest Sporting Goods Co., 828 N.E.2d 1092, 1098 (Ill. 2005) ("If the underlying complaint alleges facts within or potentially within policy coverage, an insurer is obligated to defend its insured even if the allegations are groundless, false or fraudulent.").

108. Conn. Fire Ins. Co. v. Reliance Ins. Co., 208 F. Supp. 20, 27 (D. Kan. 1962).

109. Douglas R. Richmond, The Subtly Important Supplementary Payments Provision in Liability Insurance Policies, 66 DePAul L. Rev. 763, 764 (2017); see, e.g., CGL Coverage Form, supra note 2, at 8 ("We will pay, with respect to . . . any 'suit' against an insured we defend ... [a]ll expenses we incur."); Personal Auto Policy, supra note 2, at 2 ("In addition to our limit of liability, we will pay all defense costs we incur.").

110. S. Tr. Ins. Co. v. Mountain Express Oil Co., 828 S.E.2d 455, 458 (Ga. Ct. App. 2019); Core Constr. Servs. of Ill., Inc. v. Zurich Am. Ins. Co., 126 N.E.3d 694, 700 (Ill. App. Ct. 2019); Merrick v. Fischer, Rounds \& Assocs., Inc., 939 N.W.2d 795, 807 (Neb. 2020). 
play until the insured's liability is established in the third-party action. ${ }^{111}$ Unlike the duty to defend, the duty to indemnify requires actual coverage under the policy in question. ${ }^{112}$

By allowing an insurer to rely on extrinsic evidence to avoid its duty to defend where the complaint or petition alleges facts that suggest the potential for coverage but the policy does not include a groundless-claims clause, a court risks making the insurer's provision of a defense dependent on the merits of the plaintiff's claims. ${ }^{113}$ As a matter of fact, what the court in such a case is effectively saying is that an insurer must defend factually or legally baseless claims against its insured where its policy includes a groundless-claims clause, but an insurer does not have a similar defense obligation where its policy lacks such a clause. In other words, the merits of the plaintiff's claims matter to the duty to defend unless the insurer disclaims their importance. No court recognizes that approach; courts uniformly regard the merits of the underlying lawsuit as irrelevant to the insurer's duty to defend. ${ }^{114}$ Indeed, the invalidity of the plaintiff's allegations against the insured does not change the fact that the insured has been sued based on those allegations and is entitled to have the insurer prove that they are meritless in the defense of the third-party action. ${ }^{115}$

What such a court is further saying is that the duty to defend depends on actual coverage under a policy without a groundless-claims clause rather than just the potential for coverage. After all, a court, such as the federal district court in Richards, is willing to allow an insurer to use extrinsic evidence to defeat coverage where the policy omits the magic lan-

111. First Mercury Ins. Co. v. Nationwide Sec. Servs., Inc., 54 N.E.3d 323, 330 (Ill. App. Ct. 2016); Forsman v. Blues, Brews \& Bar-B-Ques, Inc., 903 N.W.2d 524, 536 (N.D. 2017); Bighorn Logging Corp. v. Truck Ins. Exch., 437 P.3d 287, 293 (Or. Ct. App. 2019); Allstate Cnty. Mut. Ins. Co. v. Wootton, 494 S.W.3d 825, 830-31 (Tex. App.-Houston [14th Dist.] 2016, pet. denied)

112. Thee Sombrero, Inc. v. Scottsdale Ins. Co., 239 Cal. Rptr. 3d 416, 420 (Ct. App. 2018) (quoting Advanced Network, Inc. v. Peerless Ins. Co., 119 Cal. Rptr. 3d 17, 23 (Ct. App. 2010)); Mt. Hawley Ins. Co. v. Casson Duncan Constr., Inc., 409 P.3d 619, 621 (Colo. App. 2016); Robbins v. Mason Cnty. Title Ins. Co., 462 P.3d 430, 435 (Wash. 2020).

113. Of course, "[t]he original purpose of the eight-corners rule was to preclude an insurance company from refusing to defend an insured based on the lack of merit of the plaintiff's case." Tri-Coastal Contractors, Inc. v. Hartford Underwriters Ins. Co., 981 S.W.2d 861, 863 (Tex. App.-Houston [1st Dist.] 1998, pet. denied). That purpose remains valid today. See id. ("Because a liability policy is a contract under which an insurance company agrees to assume both the defense of the suit and the liability if the insured was found responsible, the eight corners rule prevents the insurance company from refusing to defend based on the merits of the suit.").

114. See, e.g., Watkins v. S. Farm Bureau Cas. Ins. Co., 370 S.W.3d 848, 855 (Ark. Ct. App. 2009) ("Clearly, the duty to defend is triggered by the nature of the claims stated by the parties in their pleadings and not by an assessment of which party will or ultimately did prevail."); Mid-Continent Cas. Co. v. Royal Crane, LLC, 169 So. 3d 174, 181 (Fla. Dist. Ct. App. 2015) ("The merits of the underlying suit are irrelevant."); Air Eng'g, Inc. v. Indus. Air Power, LLC, 828 N.W.2d 565, 569-70 (Wis. Ct. App. 2013) ("[T]he duty to defend is based on the facts alleged, not on the merits of the claim.").

115. WINDT, supra note $20, \S 4: 4$. 
guage, but not to do so where the policy includes it. ${ }^{116}$ As an Illinois court once summarized matters, however, an insurer's duty to defend is not annulled by its knowledge that "the allegations [against the insured] are untrue or incorrect, or that the true facts will ultimately exclude coverage." 117

Where the merits of the plaintiff's claims against the insured and actual coverage under the policy matter, of course, is where the insurer's duty to indemnify the insured is in question. So, to make the merits of the underlying suit or actual coverage of the claims asserted relevant to the duty to defend is either to impermissibly blend the duty to defend and the duty to indemnify, or to confuse them. Settled insurance law does not accommodate that result. ${ }^{118}$

Interestingly, the Ohio Supreme Court at one point embraced the position that State Farm advocated in Richards. In Preferred Risk Insurance Co. v. Gill, ${ }^{119}$ the court was asked to determine whether Preferred Risk had a duty to defend its insured, Bradford Gill, who had murdered a little girl, Kerri Hintermeister. ${ }^{120}$ Gill pled guilty to the murder, was convicted of the crime, and sentenced to life in prison. ${ }^{121}$ Kerri's parents sued Gill for her wrongful death on a negligence theory, and Preferred Risk filed a declaratory judgment action to escape its duties to defend and indemnify Gill based on the intentional acts exclusion in its policy. ${ }^{122}$

In holding for Preferred Risk, the court saw no reason to require the insurer to defend or indemnify Gill simply because the Hintermeisters' complaint alleged conduct ostensibly within coverage. ${ }^{123}$ Gill's conviction for murder clearly took the underlying wrongful death case outside of coverage. ${ }^{124}$ As the court later explained:

Where the insurer represents to its insured that it will undertake the defense of any claim asserting injury within coverage, even where the claim is false or fraudulent, the duty to defend may arise solely from the allegations of the underlying complaint, regardless of the true facts as they are known to the insurer. However, since the appellee

116. State Farm Lloyds v. Richards, No. 4:17-CV-753-A, 2018 WL 2225084, at *2-4 (N.D. Tex. May 15, 2018).

117. Country Mut. Ins. Co. v. Dahms, 58 N.E.3d 118, 125 (Ill. App. Ct. 2016)

118. See, e.g., Advanced Sys., Inc. v. Gotham Ins. Co., 272 So. 3d 523, 526 (Fla. Dist. Ct. App. 2019) ("[A]n insurer's duty to defend is separate and distinct from its duty to indemnify, and it is more extensive.”); Irving Oil Ltd. v. ACE INA Ins. Co., 91 A.3d 594, 599 (Me. 2014) ("[T] he duty to defend and the duty to indemnify are separate issues that are analyzed under entirely different methodologies."); Arch Ins. Co. v. Sunset Fin. Servs., Inc., 475 S.W.3d 730, 733 (Mo. Ct. App. 2015) ("An insurer's duty to defend and duty to indemnify are separate and distinct."); Tibert v. Nodak Mut. Ins. Co., 816 N.W.2d 31, 42 (N.D. 2012) ("The duty to defend and the duty to indemnify are separate and distinct contractual elements.”); N. Star Mut. Ins. v. Korzan, 873 N.W.2d 57, 61 (S.D. 2015) (“An insurer's duty to defend and its duty to indemnify are separate and independent duties.").

119. 507 N.E.2d 1118 (Ohio 1987).

120. Id. at 1119 .

121. Id.

122. Id. at $1119-20$

123. Id. at 1123 .

124. Id. 
herein has promised only to defend claims for bodily injury or property damage "to which this coverage applies," the true facts are determinative of the duty to defend. Where the true facts are such that the insured's conduct was outside the coverage of the policy, the claim is not one "to which this coverage applies," and the insurer has no obligation to defend the insured.

We hold, therefore, where the insurer does not agree to defend groundless, false or fraudulent claims, an insurer's duty to defend does not depend solely on the allegations of the underlying tort complaint. ${ }^{125}$

The Ohio Supreme Court's stance in Gill is unsupportable for the reasons outlined above in connection with Richards. ${ }^{126}$ Indeed, the court subsequently retreated from its position in Gill in Cincinnati Insurance Co. v. Colelli \& Associates, Inc., ${ }^{127}$ where it limited the holding in Gill to the facts of that case. ${ }^{128}$ Ohio courts have since applied the eight-corners rule regardless of whether the policy at issue included a groundless-claims clause, ${ }^{129}$ as have federal courts applying Ohio law, 130 although references to that language have lingered in courts' descriptions of insurers' duty to defend.131 Again, when describing the scope of the duty to defend, "groundless, false or fraudulent" phrasing is redundant. ${ }^{132}$

\section{B. Collusion as Justifying the Use of Extrinsic Evidence to Defeat the Duty to Defend}

\section{Along Comes Avalos}

Richards was not the final word on extrinsic evidence in Texas in 2020. Soon after deciding Richards, the Texas Supreme Court decided Loya Insurance Co. v. Avalos. ${ }^{133}$ In that case, Loya Insurance Company (Loya)

125. Id. at 1124 .

126. The Gill court's denial of coverage is supportable, however, based on the argument that an insurer should be able to use extrinsic evidence to refuse a defense even if the evidence arguably relates to the merits of the allegations against the insured where the evidence is incontrovertible. Examples include cases where (1) the insured has been convicted of a crime that establishes the intent to harm the plaintiff or the victim; or (2) the insured's conviction of a crime triggers a criminal act, criminal conviction, or illegal act exclusion in the subject insurance policy. See infra Part III.

127. 767 N.E.2d 717 (Ohio 2002).

128. Id. at 717 .

129. See, e.g., GNFH, Inc. v. W. Am. Ins. Co., 873 N.E.2d 345, 351 (Ohio Ct. App. 2007) ("In light of the holding in Colelli, coverage in the present case will depend on the allegations in the complaint.").

130. See, e.g., Younglove Constr., LLC v. PSD Dev., LLC, 724 F. Supp. 2d 847, 851 n.3 (N.D. Ohio 2010) (noting that the Colelli clarified that the eight-corners rule applies to all liability insurance policies), vacated on other grounds, 767 F. Supp. 2d 820 (N.D. Ohio 2011).

131. See, e.g., Sharonville v. Am. Emps. Ins. Co., 846 N.E.2d 833, 837 (Ohio 2006) (“An insurer has an absolute duty to defend an action when the complaint contains an allegation in any one of its claims that could arguably be covered by the insurance policy, even in part and even if the allegations are groundless, false, or fraudulent.").

132. See supra notes 96-109 and accompanying text.

133. 610 S.W.3d 878 (Tex. 2020). 
insured Karla Flores Guevara under an automobile liability policy. ${ }^{134}$ The Loya policy expressly excluded coverage for Guevara's husband, Rodolfo Flores. ${ }^{135}$ Unfortunately, Flores drove Guevara's car anyway, and he got into a wreck with a car occupied by Osbaldo Hurtado Avalos and Antonio Hurtado (the Hurtados). ${ }^{136}$ Flores, Guevara, and the Hurtados huddled and agreed to tell the police and Loya that Guevara was driving her car at the time of the accident-not Flores. ${ }^{137}$

The Hurtados sued Guevara in connection with the accident. ${ }^{138}$ Loya accepted Guevara's defense and appointed counsel to represent her. ${ }^{139}$ Then, before her deposition, Guevara told her defense lawyer about the parties' scheme and confessed that Flores had been driving her car. ${ }^{140}$ In response to this revelation, Guevara's lawyer canceled her deposition, and Loya withdrew its defense and denied coverage. ${ }^{141}$ The Hurtados subsequently moved for summary judgment against Guevara and won slightly more than $\$ 450,000.142$

Guevara assigned her rights against Loya to the Hurtados, who then sued Loya on various theories for denying Guevara a defense and indemnity. ${ }^{143}$ Loya counterclaimed for breach of contract and fraud, and further sought "a declaratory judgment that it owed no coverage and had no duty to defend because Flores, an excluded driver, was driving at the time of the accident." 144 Loya deposed Guevara, who testified that Flores was the culpable driver. ${ }^{145}$ Loya then moved for summary judgment because it had no duty to defend or indemnify Guevara, and attached excerpts from Guevara's deposition transcripts to support its motion. ${ }^{146}$

The trial court sustained Loya's motion, commenting "at the hearing on the motion that the Hurtados were 'asking [it] to ignore every rule of justice and help [them] perpetuate a fraud." 147 The Hurtados appealed to the Texas Court of Appeals, where they argued that the trial court erroneously granted summary judgment to Loya because, applying the eight-corners rule, Loya "had a duty to defend ... based on the terms of the insurance policy and the face of the pleadings ...., which alleged Guevara was driving at the time of the accident." 148 The appellate court

134. Id. at 880 .

135. Id.

136. Id.

137. Id.

138. Id.

139. Id.

140. Id.

141. Id.

142. Id.

143. Id.

144. Id.

145. Id.

146. Id.

147. $I d$. (second alteration in original) (quoting the trial court).

148. Id. 
accepted the Hurtados' argument and reversed the trial court. ${ }^{149}$ Loya successfully petitioned the Texas Supreme Court for review of the Court of Appeals' decision. ${ }^{150}$

The Texas Supreme Court acknowledged that while it had steadfastly enforced the eight-corners rule over the years, it had also left open the possibility that it might someday permit the use of extrinsic evidence to extinguish an insurer's duty to defend in an appropriate case. ${ }^{151}$ Pointedly, the court had "noted twice before that collusive fraud by the insured might provide the basis for an exception" to the eight-corners rule. ${ }^{152}$ The court had most recently expressed this view in a 2009 decision, Pine Oak Builders, Inc. v. Great American Lloyds Insurance Co. ${ }^{153}$ where the court suggested without deciding that "an exception to the eight-corners rule might exist where the parties to the underlying suit collude to make false allegations that would invoke the insurer's duty to defend." 154 Now, the Avalos court announced, it was presented with just the situation it had posited in Pine Oak. ${ }^{155}$

The Avalos court examined the record and easily determined that the Hurtados' allegations that were intended to trigger Loya's duties to defend and indemnify Guevara were false. ${ }^{156}$ The evidence demonstrated that Flores-not Guevara-was driving Guevera's car at the time of the accident. ${ }^{157}$ The trial court had practically begged the Hurtados to point to evidence that someone other than Flores was driving the car that hit them, which would have spared them summary judgment, but they could not do so (because no such evidence existed). ${ }^{158}$ With respect to collusion, it was clear that Flores, Guevara, and the Hurtados had agreed to lie about who was driving Guevara's car "to trigger Guevara's insurance coverage and [Loya's] duty to defend." ${ }^{159}$ Guevara's deposition testimony was conclusive evidence of the parties' scheme. ${ }^{160}$

The Avalos court concluded that given the eight-corners rule's contractual piers, the rule does not preclude courts from considering "extrinsic evidence regarding collusive fraud by the insured in determining the insurer's duty to defend." 161 Although an insurer must defend its insured against fraudulent allegations by a third-party, "the insurer [never] agreed to undertake, and the insured has not paid for, a duty to defend

149. Avalos v. Loya Ins. Co., 592 S.W.3d 138, 145-46 (Tex. App.-San Antonio 2018), rev'd, 610 S.W.3d 878, 884 (Tex. 2020).

150. See Avalos, 610 S.W.3d at 879 (noting that the court was deciding the case on a petition for review from the Court of Appeals for the Fourth District of Texas).

151. Id. at 881

152. Id.

153. 279 S.W.3d 650 (Tex. 2009).

154. Id. at 654 n.23.

155. Avalos, 610 S.W.3d at 882 .

156. Id.

157. Id.

158. $I d$.

159. Id.

160. Id.

161. Id. 
the insured against fraudulent allegations brought about by the insured itself." 162 Consequently, "an insurer owes no duty to defend when there is conclusive evidence that groundless, false, or fraudulent claims against the insured have been manipulated by the insured's own hands . . . to secure a defense and coverage where they would not otherwise exist."163

Retreating, the Hurtados argued that even recognizing a collusive fraud exception to the eight-corners rule, the trial court erred by granting summary judgment because the exception surfaced in their suit against Loya for breaching its duty to defend, not in a declaratory judgment action by Loya before it withdrew Guevara's defense. ${ }^{164}$ According to the Hurtados, an insurer should have to obtain a judicial declaration that it has no duty to defend before it may pull a defense. ${ }^{165}$ Without such a determination, the Hurtados contended, "an insurer confronted with undisputed evidence of collusive fraud designed to trigger its duty to defend must continue defending its insured." 166 The Avalos court rejected this argument for two reasons. ${ }^{167}$

First, a declaratory judgment action requires a justiciable controversy, and an insurer presented with clear evidence of its insured's collusion might conclude that there is no justiciable controversy. ${ }^{168}$ Nor would requiring an insurer to pursue "a declaratory judgment action promote prompt and efficient dispute resolution if there is conclusive evidence that the insured lied in order to secure a defense and coverage." 169 To the contrary, making an insurer prosecute a declaratory judgment action in this situation would waste the parties' time, increase their expenses, squander judicial resources, and hamper insurers' ability to promptly determine their defense and possible indemnity obligations. ${ }^{170}$ Second, an insurance company that breaches its duty to defend risks significant liability under several causes of action. ${ }^{171}$ That threat should help ensure that insurers will withdraw a defense without first obtaining a declaratory judgment only in slam-dunk cases. ${ }^{172}$ For that matter, the Avalos court urged insurers generally to pursue declaratory judgment actions to ascertain their duty to defend. ${ }^{173}$

The Avalos court concluded that when deciding whether an insurer owes a duty to defend, "a court may consider extrinsic evidence regarding whether the insured and a third party suing the insured colluded to make false representations of fact in that suit for the purpose of securing a de-

162. Id. (emphasis omitted).

163. Id.

164. Id.

165. Id.

166. Id. at $882-83$

167. Id. at 883 .

168. Id.

169. Id.

170. Id.

171. Id.

172. Id. at 884 .

173. Id. 
fense and coverage where they would not otherwise exist." 174 Accordingly, the Texas Supreme Court reversed the lower appellate court and reinstated the trial court judgment for Loya. ${ }^{175}$

\section{Analysis}

The Avalos court reached the correct result. While an insured can reasonably expect her insurer to defend her against a third party's fraudulent allegations, she cannot reasonably believe that her insurer will defend her against fraudulent claims that she helped fabricate. ${ }^{176}$ Of course, as noted earlier, the risk of collusion between an insured and a plaintiff is one of the eight-corners rule's material disadvantages. ${ }^{177}$

The parties' conduct in Avalos satisfied any possible definition of collusion. ${ }^{178}$ In terms of considering the use of extrinsic evidence to excuse an insurer's duty to defend, whether in Texas or elsewhere, however, it must be understood that false allegations in a plaintiff's complaint or petition, without more, do not evidence or equal collusion. ${ }^{179}$ Thus, "[t]he plaintiff may try to plead the case [into] coverage and allege facts that are known to be false. The insurer in [such a] case still has a duty to defend even if the allegations are false or fraudulent." 180 Or, as a Texas federal court recently wrote in National Liability \& Fire Insurance Co. v. Young, ${ }^{181}$ a plaintiff's "[a]rtful pleading" or "gamesmanship" in crafting allegations or amending a pleading to assert facts that trigger coverage does not constitute collusion justifying an insurer's resort to extrinsic evidence to ex-

174. $I d$.

175. Id.

176. Brief for Texas Ass'n of Defense Counsel as Amicus Curiae Supporting Loya Insurance at 2, Loya Ins. Co. v. Avalos, No. 18-0837, 2018 WL 6830055 (Tex. May 1, 2020).

177. JERRY \& RichMOND, supra note 9, at 699.

178. Different dictionaries define collusion differently. Compare Collusion, AMERICAN Heritage Dictionary of the English Language 363 (4th ed. 2009) (defining collusion as "[a] secret agreement between two or more parties for a fraudulent, illegal, or deceitful purpose”), with Collusion, BLACK's LAw Dictionary 300 (9th ed. 2009) (defining collusion as "[a]n agreement to defraud another or to do or obtain something forbidden by law"). Relatedly, dictionaries are imperfect sources of authority when fixing the meaning of words, as courts and scholars have observed when interpreting statutes. See, e.g., United States v. Costello, 666 F.3d 1040, 1043 (7th Cir. 2012) ("[T]he choice among meanings [of words in statutes] must have a footing more solid than a dictionary-which is a museum of words, an historical catalog rather than a means to decode the work of legislatures." (alteration in original) (quoting Frank H. Easterbrook, Text, History, and Structure in Statutory Interpretation, 17 HARv. J.L. \& PuB. PoL'y 61, 67 (1994))). Even courts that consider dictionaries to be helpful when attempting to define statutory terms recognize that dictionary definitions are not dispositive. See, e.g., Austin v. Medicis, 230 Cal. Rptr. 3d 528, 538 (Ct. App. 2018) ("[W]hile dictionaries may sometimes be helpful, they are not dispositive."); State v. White, 583 S.W.3d 442, 447 (Mo. Ct. App. 2019) ("[W]hile the dictionary is frequently used as a tool in statutory interpretation, a dictionary definition is not the final source of guidance as to a word's plain and ordinary meaning."); State v. Carlton, 388 P.3d 1093, 1097 (Or. 2017) ("[D]ictionary definitions are guides for discernment, not blunt instruments.").

179. R. Brent Cooper, Rules Governing the Use of Extrinsic Evidence in the Duty to Defend-Proposals and Predictions, 10 J. TEx. Ins. L. 12, 22 (2010).

180. Id.

181. 459 F. Supp. 3d 796 (N.D. Tex. 2020). 
cuse its duty to defend. ${ }^{182}$ The insurer in such a case must instead focus on proving the falsity of the plaintiff's allegations in what will hopefully be the successful defense of the insured. ${ }^{183}$

Although the Avalos court understandably focused on the parties' collusion to find a way around the eight-corners rule, it could have characterized Guevara's misconduct as a breach of her duty to cooperate and affirmed Loya's withdrawal of its defense on that basis. ${ }^{184}$ To be sure, Guevara's collusion with the Hurtados still would have been the conduct constituting the breach, ${ }^{185}$ but recognizing a breach of the duty to cooperate as an exception to the eight-corners rule would have firmly rooted the exception in the language of the insurance policy. Such a result also would have avoided any arguable first step down the proverbial slippery slope that public policy exceptions to established rules are sometimes said to produce. ${ }^{186}$

To briefly explain, the insured's "duty to cooperate is essentially the flip side of the insurer's duty to defend."187 Standard insurance policies include a cooperation clause. ${ }^{188}$ For example, the standard personal auto policy states: "A person seeking any coverage must ... [c]ooperate with [the insurance company] in the investigation, settlement or defense of any claim or suit." 189 Even if a liability insurance policy did not include a cooperation clause, however, the insured's duty to cooperate with the insurer in the defense of a lawsuit would be implied. ${ }^{190}$ As a matter of contract law, where one party to an agreement promises to perform a duty that requires some degree of cooperation by the other party, a duty to cooperate is imposed on the second party. ${ }^{191}$ In fact, a principal purpose of a cooperation clause is to prevent collusion between an insured and a third party. ${ }^{192}$

A possible negative aspect of relying on a breach of the duty to cooperate to excuse an insurer's duty to defend, rather than what amounts to a

182. Id. at 801-02; see also Liberty Surplus Ins. Corp. v. Allied Waste Sys., Inc., 758 F. Supp. 2d 414, 420 (S.D. Tex. 2010) ("Artful pleading, absent evidence of collusion between the third-party claimant and the insured, does not create an exception to the general rule.").

183. Young, 459 F. Supp. 3d at 802 (quoting GuideOne Elite Ins. Co. v. Fielder Rd. Baptist Church, 197 S.W.3d 305, 311 (Tex. 2006)).

184. See Windt, supra note 20 , at $\S 4: 4$ (stating that an insured's breach of the duty to cooperate is an exception to the rule that an insurer cannot use extrinsic evidence to extinguish its duty to defend).

185. See JERRY \& Richmond, supra note 9, at 682 (describing an insured's collusion with a claimant as "a glaring breach of the duty to cooperate").

186. I do not mean to suggest that to be the result of the Avalos decision.

187. JERRY \& RichMOND, supra note 9, at 681.

188. 44 Am. JuR. 2D Insurance $\$ 1426$ (2020).

189. Personal Auto Policy, supra note 2, at 11.

190. JERRY \& RichMOND, supra note 9, at 681.

191. Id.

192. See Am. Access Cas. Co. v. Alassouli, 31 N.E.3d 803, 808 (Ill. App. Ct. 2015) ("A cooperation clause prevents collusion between the insured and injured and enables an insurer to prepare its defense to a claim.”); Staples v. Allstate Ins. Co., 295 P.3d 201, 205 (Wash. 2013) ("Cooperation clauses also guard against collusion and fraud."). 
public policy exception in a case of collusion, is that an insurer generally must show that it was prejudiced by the insured's noncooperation to deny coverage. ${ }^{193}$ On the other hand, it should be a rare case where an insured's collusion does not materially and substantially prejudice the insurer's defense of the lawsuit against the insured. ${ }^{194}$

\section{RULES FOR THE USE OF EXTRINSIC EVIDENCE TO EXCUSE AN INSURER'S DUTY TO DEFEND}

\section{A. General Guidance Concerning the Use of Extrinsic EVIDENCE}

Jurisdictions differ on whether and when insurers may rely on extrinsic evidence to excuse their duty to defend where a plaintiff's complaint or petition alleges facts that raise the potential for coverage, but it is possible to state some general rules regarding the use of extrinsic evidence in this context. In doing so, it is first important to recognize that there are three essential categories of extrinsic evidence: (1) evidence that relates solely to the merits of the plaintiff's allegations against the insured; (2) evidence that relates solely to the insurer's duty to indemnify the insured-that is, which goes solely to the question of coverage under the policy at issue; and (3) evidence that relates both to the merits of the plaintiff's claims and to coverage, evidence which might be described as overlapping evidence. ${ }^{195}$ Alternatively, it might be said that there are three categories of "actual facts" or "true facts" that courts must consider when deciding whether an insurer should be allowed to extinguish its duty to defend: (1) liability facts; (2) coverage or nonliability facts; and (3) mixed facts. ${ }^{196}$

Generally, an insurer cannot rely on extrinsic evidence that relates solely to the merits of the plaintiff's claims against the insured or on overlapping evidence to excuse its duty to defend where the plaintiff has pleaded facts that raise the potential for coverage. ${ }^{197}$ Where extrinsic evidence relates exclusively to the issue of coverage, on the other hand, an insurer should be allowed to rely on that evidence to excuse its duty to defend notwithstanding the facts alleged in the plaintiff's pleadings. ${ }^{198}$ An

193. Spore v. GEICO Indem. Co., 497 S.W.3d 704, 709 (Ark. Ct. App. 2016); Xtreme Prot. Servs., LLC v. Steadfast Ins. Co., 143 N.E.3d 128, 138 (Ill. App. Ct. 2019); Breaux v. Cozy Cottages, LLC, 151 So. 3d 183, 190 (La. Ct. App. 2014).

194. See generally Xtreme, 143 N.E.3d at 138 ("Proof of substantial prejudice requires an insurer to demonstrate that it was actually hampered in its defense by the violation of the cooperation clause." (quoting M.F.A. Mut. Ins. Co. v. Cheek, 363 N.E.2d 809, 813 (Ill. 1977))).

195. Ellen S. Pryor, Mapping the Changing Boundaries of the Duty to Defend in Texas, 31 Tex. Tech L. Rev. 869, 880 (2000).

196. See Barker, supra note 10, at 20 (referring to "actual facts," "liability facts," "nonliability facts," and "[m]ixed facts").

197. See, e.g., GuideOne Elite Ins. Co. v. Fielder Rd. Baptist Church, 197 S.W.3d 305, 308-10 (Tex. 2006) (explaining that the insurer could not rely on extrinsic evidence related to the merits of the plaintiff's claims or overlapping evidence to escape its duty to defend).

198. See, e.g., Bartkowiak v. Underwriters at Lloyd's, 39 N.E.3d 176, 181 (Ill. App. Ct. 2015) ("[P]rovided that the trial court is not, in effect, adjudicating a critical issue in the 
insurer should also be allowed to use extrinsic evidence to excuse its duty to defend even if the evidence arguably relates to the merits of the allegations against the insured or might be seen as overlapping evidence where the evidence is incontrovertible. ${ }^{199}$ Obvious examples are cases in which the insured has been convicted of a crime that establishes the intent to harm the plaintiff or victim, or the insured's conviction of any crime that triggers a criminal act, criminal conviction, or illegal act exclusion in the subject insurance policy. ${ }^{200}$

\section{B. Specific Instances Justifying the Use of Extrinsic Evidence Related Solely to Coverage to Excuse the Insurer's Duty to Defend}

The circumstances in which extrinsic evidence will relate solely to coverage, and accordingly may be used by the insurer to excuse its duty to defend, will vary by case. ${ }^{201}$ In Talen v. Employers Mutual Casualty Co. ${ }^{202}$ for example, the court held that the insurer had no duty to defend despite the ambiguous allegations in the plaintiff's complaint because the "refusal to employ" exclusion in the insured's policy meant that the plaintiff could not recover economic damages against the insured under any of his legal theories. ${ }^{203}$

By way of further example, the insureds in Kepner v. Western Fire Insurance Co. ${ }^{204}$ Harry and Velma Kepner, had a homeowner's policy with Western that contained a business pursuits exclusion. ${ }^{205}$ Harry Kepner ran his business, Harry's Pool Service, out of their home. ${ }^{206}$ The Kepners' grandson, Walter, was injured when a Harry's Pool Service employee was using a power saw during a project to convert the carport at the Kepners' house into an office for the business. ${ }^{207}$ Walter's parents sued the Kepners on his behalf, but the complaint was silent on whether the use of the power saw was related to Harry Kepner's business. ${ }^{208}$ The Arizona

underlying case, there is no reason why the trial court could not consider relevant, objective, undisputed facts in deciding the duty to defend, even if those facts fall outside the pleadings of the underlying lawsuit."); Blake v. Nationwide Ins. Co., 904 A.2d 1071, 1076 (Vt. 2006) ("Although in many cases the presence of a duty to defend can be determined by comparing . . . the policy with . . . the complaint, this is not such a case because the relevant policy exclusions involve factual questions not covered in the complaint, namely, whether the accident occurred in the scope of employment.").

199. Barker, supra note 10, at 8.

200. See id. (discussing an insured's admission of an intentional assault and an insured's criminal conviction for assault).

201. See generally Michael Menapace, Going Beyond the Four Corners to Deny a Defense: A Critique of Section 13(3) of the Restatement of Liability Insurance, 53 TORT TRIAL \& INS. PRAC. L.J. 795 (2018) (discussing the varied circumstances in which courts have approved of insurers' consideration of extrinsic evidence in denying a defense notwithstanding the eight-corners rule).

202. 703 N.W.2d 395 (Iowa 2005).

203. Id. at 407.

204. 509 P.2d 222 (Ariz. 1973).

205. Id. at 223 .

206. Id. at $222-23$.

207. Id. at 223 .

208. Id. 
Supreme Court held that Western had no duty to defend because, while the facts alleged in the complaint ostensibly brought the case within coverage, other facts outside the complaint defeated coverage by implicating the business pursuits exclusion. ${ }^{209}$ More to the point, the extrinsic facts that demonstrated that the pool service employee using the power saw was working for the business at the time of the accident were irrelevant to the merits of the plaintiffs' lawsuit. ${ }^{210}$

Although the circumstances in which an insurance company may rely on extrinsic evidence that relates solely to coverage to excuse its duty to defend are case and fact specific, some situations stand out. ${ }^{211}$

\section{The Party Seeking a Defense Is Not an Insured}

First, an insurer should be allowed to rely on extrinsic evidence to establish that the party seeking a defense is not an insured under the relevant policy. ${ }^{212}$ For example, an insurer should be allowed to use extrinsic evidence to show that the party seeking a defense does not fall within the subject policy's definition of an insured, ${ }^{213}$ or that an insured's policy was canceled at such a time as to excuse the insurer's performance. ${ }^{214}$

Weingarten Realty Management Co. v. Liberty Mutual Fire Insurance Co. $^{215}$ is an interesting Texas Court of Appeals case decided before Richards and Avalos in which the court held that the insurer could use extrinsic evidence to extinguish its duty to defend a party it did not insure..$^{216}$ Weingarten arose out of a criminal attack on Connie Johnson, who managed a store named Fashion Cents. ${ }^{217}$ Johnson sued her employer, Norstan Apparel Shops (Norstan), which used the Fashion Cents business name, and Weingarten Realty Management Co. (Weingarten Management), which she alleged was Fashion Cents' landlord. ${ }^{218}$ Norstan actually leased the Fashion Cents space from a separate company, Weingarten Realty Investors (Weingarten Investors). ${ }^{219}$

Norstan's lease with Weingarten Investors required Norstan to obtain a CGL policy naming Weingarten Investors as an additional insured.220

209. Id. at $224,226$.

210. See id. at 224 ("The proof of negligence proximately causing Walter Kepner's injuries justifies a judgment favorable to him, but the fact that the insureds' policy excludes coverage is irrelevant....").

211. The following list of situations is not intended to be exclusive or exhaustive.

212. PIH Beaverton LLC v. Red Shield Ins. Co., 412 P.3d 234, 240 (Or. Ct. App. 2018) (citing Fred Shearer \& Sons, Inc. v. Gemini Ins. Co., 240 P.3d 67, 73 (Or. Ct. App. 2010)); Restatement of the L. of Liab. Ins. § 13(3)(a) (Аm. L. Inst. 2019).

213. See Fred Shearer \& Sons, 240 P.3d at 73 (explaining the rationale for departing from the eight-corners rule in this context).

214. Patrons Oxford Mut. Ins. Co. v. Garcia, 707 A.2d 384, 386 (Me. 1998) (quoting Am. Policyholders' Ins. Co. v. Cumberland Cold Storage Co., 373 A.2d 247, 250 (Me. 1977)).

215. 343 S.W.3d 859 (Tex. App.-Houston [14th Dist.] 2011, pet. denied).

216. Id. at 865 .

217. Id. at 860 .

218. Id.

219. Id.

220. Id. 
Norstan obtained a policy with Liberty Mutual that named all of Norstan's lessors as additional insureds. 221 Meanwhile, Weingarten Management was separately insured under a CGL policy with Scottsdale Insurance Co. (Scottsdale). ${ }^{222}$ When Johnson sued Weingarten Management, the company defended itself until it exhausted its self-insured retention, at which time Scottsdale assumed the defense. ${ }^{223}$

Weingarten Management finally demanded that Liberty Mutual take over its defense as an additional insured under the Norstan policy, but Liberty Mutual refused. ${ }^{224}$ Weingarten Management defeated Johnson at trial. 225 Weingarten Management and Scottsdale then sued Liberty $\mathrm{Mu}-$ tual to recover their defense costs, asserting that Liberty Mutual had breached its duty to defend Weingarten Management because Johnson had named the company as Norstan's landlord in her petition. ${ }^{226}$ Weingarten Management and Scottsdale conceded that Weingarten Management was not Norstan's landlord but contended that Johnson's "mistaken allegation gave rise to a duty to defend because the 'eight-corners rule' restricted the trial court from looking outside the pleadings and insurance policy to determine Weingarten Management was not the true lessor."227

The parties filed cross-motions for summary judgment. ${ }^{228}$ In weighing the motions, "the trial court examined evidence extrinsic to Johnson's petition ... and the Liberty Mutual policy to determine [that] Weingarten Management was not a lessor and therefore was not entitled to coverage under the Liberty Mutual policy's 'additional insured' endorsement."229 The trial court granted Liberty Mutual's summary judgment motion, and Weingarten Management and Scottsdale appealed. ${ }^{230}$

On appeal, Weingarten Management and Scottsdale contended that the trial court improvidently awarded Liberty Mutual summary judgment because it erroneously considered extrinsic evidence in doing so rather than adhering to the eight-corners rule. ${ }^{231}$ But the Weingarten court reasoned that the appellants' eight-corners rule argument missed the mark:

The rationale behind the eight-corners rule is to require insurers to defend the insured against all claims, even those without merit. To the insured, a meritless claim still requires a defense. But the protection the eight-corners rule provides exists for the benefit only of the insured. It is the insured who is entitled to trust that his insurer will defend him against all covered claims, meritorious or not. A stranger

\footnotetext{
221. Id.

222. $I d$.

223. Id. at 860-61.

224. Id. at 861 .

225. Id.

226. Id.

227. Id.

228. Id.

229. Id.

230. Id.

231. Id. at 862 .
} 
to the policy neither needs nor should expect this benefit. ${ }^{232}$

Consistent with the quoted language, Liberty Mutual argued that it had no duty to defend Weingarten Management because it was not an additional insured under the Norstan policy "and, as a total stranger to the policy, [was] not entitled to a defense against any claim." 233 Enforcing the eight-corners rule here would serve no purpose traditionally assigned to the rule. ${ }^{234}$ Rather than disputing the merits of Johnson's suit, Liberty Mutual had based its refusal to defend on a "pure coverage" issue. ${ }^{235}$

On these facts, the Weingarten court saw the utility of "a very narrow exception to the eight-corners rule." 236 As the court explained, "[t]he exception applies only when an insurer establishes by extrinsic evidence that a party seeking a defense is a stranger to the policy and could not be entitled to a defense under any set of facts." 237 For this limited exception to apply, "the extrinsic evidence must go strictly to an issue of coverage without contradicting any allegation in the third-party claimant's pleadings material to the merits of that underlying claim."238

Weingarten Management and Scottsdale tried to escape the court's exception to the eight-corners rule by arguing that the extrinsic evidence here related to the merits of Johnson's claims as well as to coverage. ${ }^{239}$ They reasoned that Weingarten Management's alleged status as Norstan's landlord was relevant to Johnson's alleged status as Fashion Cents' invitee, such that Weingarten Management owed her a duty of care. ${ }^{240}$ Weingarten Management and Scottsdale further argued that, because Weingarten Management had a right of control over the Fashion Cents space under the Norstan lease, Weingarten Management's alleged status as Norstan's landlord was key to "the scope of the duty owed to Johnson." 241 The Weingarten court, however, easily dispatched these arguments:

It is true that in a claim properly brought against an insurer by an actual insured, the existence and terms of a lease could be a significant factor in determining whether a landlord retained control over a leased premises. But here Liberty Mutual seeks to introduce evidence that Weingarten Management is not a lessor not to undermine the merits of the plaintiff's claim but to establish that Weingarten Management is a stranger to the policy. The appellants may see the lessor allegation as important to the merits of their case, but Liberty Mutual's interest in contradicting it is confined to disputing Wein-

232. Id. at $864-65$ (citation omitted)

233. Id. at 865 .

234. Id.

235. Id.

236. Id.

237. Id.

238. Id. (citing GuideOne Elite Ins. Co. v. Fielder Rd. Baptist Church, 197 S.W.3d 305, 310 (Tex. 2006)).

239. Id. at 868 .

240. Id.

241. Id. at 868-69. 
garten Management's status as an "insured." 242

Weingarten Management was never insured with Liberty Mutual and its only claim to a defense from Liberty Mutual was its mistaken identification as Norstan's lessor in Johnson's petition. ${ }^{243}$ It was therefore proper for the trial court to consider extrinsic evidence in awarding Liberty $\mathrm{Mu}$ tual summary judgment. ${ }^{244}$

\section{The Vehicle or Other Property Involved in the Occurrence Is Not Covered Under the Policy in Question}

Second, an insurer should be allowed to use extrinsic evidence to deny a duty to defend where the vehicle or other property involved in the occurrence is not covered under the policy under which a defense is demanded and there is no other potential basis for coverage. ${ }^{245}$ In Rowell $v$. Hodges ${ }^{246}$ for example, the insured, Hardy Hodges, owned a 1958 Cadillac and a 1955 Cadillac. ${ }^{247} \mathrm{He}$ insured the 1958 Cadillac with Northwestern Mutual Insurance Co. (NMIC). ${ }^{248}$ Hodges was in an accident while driving his 1955 Cadillac. ${ }^{249}$ NMIC investigated the accident and established that Hodges was driving his 1955 Cadillac at the time of the accident-not his insured 1958 model. ${ }^{250}$

A minor passenger in the other car involved in the accident and her father sued Hodges but pleaded only that Hodges was "operating 'an automobile" "at the time of the accident.251 NMIC declined to defend Hodges in the lawsuit because he was not driving the insured vehicle and therefore did not qualify as an insured. ${ }^{252}$ The plaintiffs obtained a $\$ 20,000$ judgment against Hodges and thereafter tried to collect the judgment through a garnishment action against NMIC. ${ }^{253}$

The Rowell court determined that NMIC acceptably relied on extrinsic evidence in declining to defend Hodges. ${ }^{254}$ As the court explained:

In a sense, to say here that the [NMIC] must gauge its obligation

strictly by the ... Complaint, and put blinders on, so to speak, to

what it actually knows and has definitely ascertained, is somewhat

242. Id. at 869 .

243. Id.

244. $I d$.

245. Restatement of the L. of Liab. Ins. § 13(3)(b) (Am. L. Inst. 2019); see, e.g. Nationwide Mut. Fire Ins. Co. v. Keen, 658 So. 2d 1101, 1103 (Fla. Dist. Ct. App. 1995) ("The insured conceded to the carrier shortly after the incident that a critical and objective fact placed any claim beyond coverage, i.e. that he operated the [boat] with an engine more powerful than the coverage afforded. That concession was backed up by corroborative evidence.").

246. 434 F.2d 926 (5th Cir. 1970).

247. Id. at 928

248. Id. at 927-28.

249. Id. at 928

250. Id.

251. Id. at 929 .

252. Id. at 928 .

253. Id.

254. Id. at 930. 
archaic, considering the nature of our present system of notice pleading. The Court simply cannot find any just or logical reason why it should be held that the mere allegation . . . that Hardy Hodges was operating 'an automobile' thereby invokes a contractual obligation to defend the suit brought by the Plaintiffs, when reality, i.e., the actual identity of the vehicle involved in the accident, told everybody that there was not and never had been any insurance coverage for ... Hodges, in the first place. ${ }^{255}$

As a result, the plaintiffs were not entitled to collect their judgments from NMIC. ${ }^{256}$

\section{The Underlying Harm Occurred Outside the Policy Period}

Most liability insurance policies are occurrence based, meaning that the insurer has a duty to defend and indemnify the insured when the bodily injury or property damage is caused by an "occurrence." 257 Standard liability policies typically define the term occurrence to mean "an accident, including continuous or repeated exposure to substantially the same general harmful conditions." 258 Furthermore, the "bodily injury" or "property damage" caused by the occurrence must occur during the policy period for coverage to lie. ${ }^{259}$ "In most cases, the damage occurs at the same time as the event, so it is often said that occurrence policies provide coverage if the event insured against takes place during the policy period, regardless of when the claim is presented." 260

That explanation lays the foundation for the third exception to the eight-corners rule, which recognizes that an insurer should be allowed to use extrinsic evidence to show that it owes no duty to defend where the injury or damage being sued over occurred outside the policy period. ${ }^{261}$ In Fireman's Fund Insurance Co. v. Hyster-Yale Group, Inc. ${ }^{262}$ for example, the court held that the insurer had no duty to defend asbestos personal injury cases against its insured where it could establish that the plaintiff's injury occurred outside the effective dates of the policy under

255. Id.

256. Id.

257. See, e.g., CGL Coverage Form, supra note 2, at 1.

258. Id. at 15 .

259. Id. at 1 .

260. JERRY \& RichMOND, supra note 9, at 423.

261. See, e.g., Avondale Indus., Inc. v. Travelers Indem. Co., 774 F. Supp. 1416, 1423-27 (S.D.N.Y. 1991) (permitting consideration of extrinsic evidence and concluding that because Travelers would be unable to demonstrate that any events relevant to the underlying actions occurred during the coverage periods of two other insurers, Highlands and Commercial Union (CU), Travelers would not be entitled to a declaration that Highlands and $\mathrm{CU}$ had to indemnify Avondale, and the court could therefore determine that Highlands and CU were relieved of any duty to defend Avondale); Guar. Nat'l Ins. Co. v. C de Baca, 907 P.2d 210, 214 (N.M. Ct. App. 1995) ("Of course, when the question of coverage turns on whether the events alleged in the complaint occurred during the policy period, it is necessary to look outside the four corners of the complaint. The complaint will provide no information on the effective dates of the policy.").

262. 135 N.E.3d 499 (Ohio Ct. App. 2019). 
which coverage was sought. ${ }^{263}$ Similarly, in Polarome International, Inc. $v$. Greenwich Insurance Co., ${ }^{264}$ a New Jersey court held that where the plaintiffs' complaints were ambiguous, two insurers could rely on extrinsic evidence establishing that the plaintiffs' chemical exposure had ceased and their injuries were diagnosed before the insurers' policies took effect. ${ }^{265}$ As a result, the insurers did not breach their duties to defend the insured when they withdrew their defenses based on extrinsic facts they learned in their investigations of the plaintiffs' allegations. ${ }^{266}$

\section{Lateness Under a Claims-Made-and-Reported or Claims-Made Policy}

Fourth, an insurer should be allowed to use extrinsic evidence to deny a duty to defend where the insured is covered under a claims-made-andreported insurance policy and does not report the claim to the insurer within the policy period or any extended reporting period. ${ }^{267}$ To briefly explain, a claims-made-and-reported policy differs from an occurrencebased policy in key respects. ${ }^{268}$ For there to be coverage under a claimsmade-and-reported policy, a claim against the insured must be made within the policy period, and the insured must report the claim to the insurance company within the policy period or within an extended reporting period provided for in the policy. ${ }^{269}$ An extended reporting period in a claims-made-and-reported policy extends the insured's time in which to report a claim for some specified period (e.g., sixty days) after the end of the policy period and still receive coverage. ${ }^{270}$

Claims-made-and-reported policies are often referred to as "claimsmade" policies, ${ }^{271}$ although there are, in fact, differences between the two types of policies. ${ }^{272}$ Quickly, under a claims-made policy, coverage is triggered when a claim is made against the insured within the policy period. ${ }^{273}$ A claims-made policy, much like an occurrence-based policy, then requires the insured to provide notice of the claim to the insurer " as soon as practicable' or within a stated period." 274 Just as an insurer should be able to use extrinsic evidence to excuse its duty to defend under a claims-made-and-reported policy, so too should it be able to

\footnotetext{
263. Id. at 507.

264. 961 A.2d 29 (N.J. Super. Ct. App. Div. 2008).

265. Id. at 50 .

266. Id.

267. Restatement of the L. of Liab. Ins. § 13(3)(c) (Ам. L. Inst. 2019).

268. See JeRry \& Richmond, supra note 9, at 422-23 (explaining the differences between occurrence-based and claims-made-and-reported policies).

269. Id. at 423 .

270. See, e.g., Aspen Square, Inc. v. Am. Auto. Ins. Co., No. 2:18-CV-02255-JAR-JPO, 2019 WL 1115261, at *3 (D. Kan. Mar. 11, 2019) (quoting the basic extended reporting period in a claims-made-and-reported insurance policy).

271. JERRY \& RichMOND, supra note 9, at 423.

272. See Anderson v. Aul, 862 N.W.2d 304, 311 (Wis. 2015) (explaining the differences between claims-made and claims-made-and-reported insurance policies).

273. Id.

274. Id.
} 
avoid its duty to defend where it can show, based on extrinsic evidence, that a claim was not timely asserted under a claims-made policy. ${ }^{275}$

Edwards v. Lexington Insurance Co. ${ }^{276}$ is the leading case for the proposition that an insurer may use extrinsic evidence to excuse its duty to defend under a claims-made or claims-made-and-reported policy.277 In October 2002, Ernest Edwards was injured when his Game Tracker safety harness malfunctioned, and he fell from the tree stand he was using to hunt. ${ }^{278} \mathrm{He}$ obtained a default judgment of nearly $\$ 2$ million against Game Tracker after Lexington Insurance Company (Lexington) declined to defend Game Tracker against Edwards's lawsuit under any of the three policies that Lexington had issued to the company. ${ }^{279}$ One of those policies was a claims-made policy; Lexington contended that Edwards never notified either it or Game Tracker of his claim against Game Tracker during the policy period, which ran from April 2002 to June 2003.280

Edwards sued Lexington to satisfy his judgment against Game Tracker, which was bankrupt. 281 "During discovery, Lexington sought proof that Edwards had provided notice within the [policy] period." 282 Edwards was unable to say whether he had given notice of his claim to Game Tracker or Lexington during the policy period. ${ }^{283}$ In fact, the only evidence in the record established that Edwards did not give Game Tracker formal notice of his injury until January 2004. ${ }^{284}$ Based on Edwards's inability to offer evidence that he had timely given notice of his claim to Game Tracker or Lexington, the district court found that "the claims-made insurance policy did not cover Edwards'[s] claim" and awarded Lexington summary judgment. ${ }^{285}$

On appeal to the First Circuit, Edwards argued that under controlling Maine law, the district court was bound to apply the eight-corners rule to determine Lexington's duty to defend. ${ }^{286}$ Thus, he reasoned, the district court erred by relying on extrinsic evidence to decide that Lexington had no duty to defend Game Tracker. ${ }^{287}$

The court rejected Edwards's argument. ${ }^{288}$ As the court explained, the eight-corners rule "is appropriately invoked in the context of occurrence

275. See, e.g., Hasbrouck v. St. Paul Fire \& Marine Ins. Co., 511 N.W.2d 364, 370 (Iowa 1993) (affirming summary judgment for the insurer based on evidence outside the scope of the pleadings where the insured provided late notice of a medical malpractice claim under a claims-made policy).

276. 507 F.3d 35 (1st Cir. 2007).

277. Id. at 40-41.

278. Id. at 38 .

279. Id.

280. Id. at 38-39.

281. Id. at 39.

282. Id.

283. Id.

284. Id.

285. Id.

286. Id. at 40 .

287. Id.

288. Id. at 40-41. 
policies because the complaint in describing the incident will usually provide adequate information to determine whether-at least as allegedthe incident is within the scope of the insurance policy." 289 But the eightcorners rule cannot be inflexibly applied to "claims-made policies where the determinative event is the timing of the claim, a fact that likely will be-and in this case was-irrelevant to the merits of the underlying tort suit, and therefore absent from the pleadings." 290 Therefore, the district court did not err in granting Lexington's summary judgment motion on this point. ${ }^{291}$ After considering additional arguments, the Edwards court affirmed the district court's judgment for Lexington. ${ }^{292}$

\section{Collusion or Other Lack of Cooperation}

As we saw in Avalos, an insured's collusion with a claimant justifies the insurer's use of extrinsic evidence to excuse its duty to defend. ${ }^{293}$ Of course, proof of collusion requires extrinsic evidence, and there is no valid reason to effectively foster or tolerate collusion by insureds through strict adherence to the eight-corners rule. Other forms of noncooperation established through extrinsic evidence may also excuse an insurer's duty to defend regardless of the factual allegations in the plaintiff's complaint or petition. 294

\section{Incontrovertible Evidence Establishing a Coverage DEFENSE}

As noted above, an insurer should also be able to use extrinsic evidence to refuse a defense, even if the evidence arguably relates to the merits of the allegations against the insured or qualifies as overlapping evidence, where the evidence is incontrovertible. Ready examples include cases (1) where the insured has been convicted of a crime that establishes the intent to harm the plaintiff or the victim; or (2) where the insured's conviction of a crime triggers a criminal act, criminal conviction, or illegal act exclusion in the subject insurance policy. ${ }^{295}$ In such cases, the court may hold that the insured's criminal conviction collaterally estops the in-

289. Id. (citing Liberty Mut. Ins. Co. v. Graham, 473 F.3d 596, 599-600 (5th Cir. 2006)).

290. Id. at 41 .

291. Id.

292. Id. at $41-43$.

293. Loya Ins. Co. v. Avalos, 610 S.W.3d 878, 882, 884 (Tex. 2020).

294. Patrons Oxford Mut. Ins. Co. v. Garcia, 707 A.2d 384, 386 (Me. 1998) (quoting Am. Policyholders' Ins. Co. v. Cumberland Cold Storage Co., 373 A.2d 247, 250 (Me. 1977)); WINDT, supra note 20, at $\S 4: 4$.

295. Generally, to trigger a criminal act exclusion, an insurer must establish that the insure committed a criminal act, but the insurer is not required to also show that the insured intended to injure the plaintiff or victim. See SECURA Supreme Ins. Co. v. M.S.M., 755 N.W.2d 320, 325 (Minn. Ct. App. 2008) (describing this approach as the majority rule). But see Webb v. USAA Cas. Ins. Co., 457 P.3d 1258, 1271 (Wash. Ct. App. 2020) ("[A] criminal act exclusion ... [applies] only to serious criminal conduct 'done with malicious intent, from evil nature, or with a wrongful disposition to harm or injure other persons or property." (first alteration in original) (quoting Allstate Ins. Co. v. Raynor, 21 P.3d 707, 712 (Wash. 2001))). 
sured from denying any intent to harm the plaintiff or victim, ${ }^{296}$ or the court may treat the insured's conviction as dispositive of the insured's intent to harm with no mention of collateral estoppel or issue preclusion. ${ }^{297}$

\section{Criminal Conviction Establishing an Intentional Injury}

Standard liability insurance policies do not insure against insureds' intentional injury of third parties for two reasons. ${ }^{298}$ First, occurrencebased policies define the term occurrence to mean "an accident," 299 and an insured's intentional injury of a third party is no accident. ${ }^{300}$ Second, standard insurance policies include intentional acts exclusions that typically exclude coverage for bodily injury or property damage "expected or intended by an 'insured," "albeit with an exception for the use of reasonable force to protect persons or property. ${ }^{301}$ Thus, an insured's criminal act that includes intent as an element cannot be considered an occurrence and should operate to excuse the insurer's duty to defend because there is no possibility of coverage under the policy. Relatedly, an insurer should be able to offer evidence of an insured's criminal conviction to excuse its duty to defend under an intentional acts exclusion even if the plaintiff alleges that the insured negligently caused the subject harm. ${ }^{302}$ American

296. See, e.g., Esurance Ins. Co. v. Hamm, 387 F. Supp. 3d 1134, 1140 (D. Or. 2019) (explaining that the insured's guilty plea and conviction had a preclusive effect with respect to whether the victim's injury was the reasonably expected result of an insured's criminal act); Allstate Ins. Co. v. Morgan, 123 F. Supp. 3d 1266, 1275-76 (D. Or. 2015) (applying issue preclusion and stating that an insurer "has no duty to defend when a criminal conviction incontrovertibly establishes the insurer does not cover an injury").

297. See, e.g., Century Sur. Co. v. Seidel, 893 F.3d 328, 333-36 (5th Cir. 2019) (applying Texas law in connection with a criminal act exclusion).

298. As the following text explains, an insured's allegedly wrongful act may not constitute an "occurrence" and it may further fall within a policy exclusion. The fact that an act or event does not qualify as an "occurrence" and is also excluded from coverage does not make either the "occurrence" aspect of the insuring agreement or the exclusion surplusage. Am. Fam. Mut. Ins. Co. v. Mid-Am. Grain Distribs., LLC, 958 F.3d 748, 757 (8th Cir. 2020) (applying Missouri law).

299. CGL Coverage Form, supra note 2, at 15; Homeowners 3-Special Form, supra note 2 , at 2 .

300. See, e.g., Allstate Ins. Co. v. Wilson, 18 F. Supp. 3d 156, 163 (D. Conn. 2014) (finding it clear from the complaint in the underlying action that the plaintiff's negligence claims arose out of her intentional sexual assault by two insureds, such that the complaint did not allege an accident, and therefore Allstate had no duty to defend or indemnify the insureds because there was no occurrence); USAA Cas. Ins. Co. v. Carr, 225 A.3d 357, 360-62 (Del. 2020) (explaining that whether an incident is an accident in the context of a liability insurance policy must be determined from the insured's viewpoint and concluding that a teenager's senseless assault on a classmate was not an accident); Lambert v. Safeco Ins. Co. of Am., 87 So. 3d 1123, 1128 (Miss. Ct. App. 2012) (finding that because the insured intentionally fired his pistol at the car in which the decedent was riding, there was no accident or occurrence).

301. Homeowners 3-Special Form, supra note 2, at 19; CGL Coverage Form, supra note 2 , at 2 .

302. See, e.g., W. Nat'l Assurance Co. v. Wipf, 702 F. App'x 542, 544 (9th Cir. 2017) (applying Washington law); Am. Fam. Mut. Ins. Co. v. Savickas, 739 N.E.2d 445, 453-54 (Ill. 2000) (concluding that the insured's criminal conviction for first-degree murder collaterally estopped the administrator of the victim's estate from contending that the victim's injury was not expected or intended); State Mut. Ins. Co. v. Bragg, 589 A.2d 35, 38 (Me. 
Family Mutual Insurance Co. v. Savickas ${ }^{303}$ is a representative case.

In Savickas, Michael Savickas shot and killed Thomas Vinicky. ${ }^{304}$ Savickas was convicted of first degree murder. ${ }^{305}$ The administrator of Vinicky's estate, Elizabeth Vinicky, sued Savickas for wrongful death. ${ }^{306}$ Her amended complaint included four causes of action, two of which alleged an intentional tort by Savickas and two that alleged that Savickas had either negligently shot Thomas or had negligently assessed his need to defend himself against Thomas. ${ }^{307}$ Savickas tendered his defense to his homeowner's carrier, American Family. ${ }^{308}$ American Family agreed to defend Savickas but promptly filed a declaratory judgment action seeking a declaration that it had no duty to defend or indemnify him. ${ }^{309}$

American Family moved for summary judgment in the declaratory judgment action based on the intentional acts exclusion in its policy, which stated that coverage did not apply "to bodily injury or property damage "which [was] expected or intended by any insured." 310 American Family supported its motion with a certified copy of Savickas's conviction, a copy of the appellate opinion affirming Savickas's conviction, and excerpts from the transcript of Savickas's criminal trial in which he admitted that he intentionally shot Thomas Vinicky. ${ }^{311}$ The trial court granted American Family's summary judgment motion but an appellate court reversed, reasoning that the negligence allegations in the complaint triggered American Family's duty to defend. ${ }^{312}$

American Family appealed to the Illinois Supreme Court, which held that Savickas's murder conviction collaterally estopped him from denying

1991) ("[M]urder, attempted murder and sexual abuse of a child convictions are narrow exceptions to the general rule that determines a duty to defend solely from the insurance contract and the allegations of the complaint."); Aetna Cas. \& Sur. Co. v. Sprague, 415 N.W.2d 230, 232 (Mich. Ct. App. 1987) ("The trial court did not err in concluding, based on the conviction and on the deposition evidence presented, that there was no genuine issue of material fact as to whether [the insured] expected or intended to kill [the victim]. Therefore, there was no duty to defend or provide coverage."); Burns v. Underwriters Adjusting Co., 765 P.2d 712, 712-13 (Mont. 1988) (explaining that the insured pled guilty to felony aggravated assault and that the allegations of negligence in the plaintiff's complaint did not determine the insurers' duty to defend); Home Mut. Ins. Co. v. Lapi, 596 N.Y.S.2d 885, 887 (App. Div. 1993) (reasoning that the insured's guilty plea trumped his incredible claim that he did not mean to injure the plaintiff and rejecting the insured's transparent attempt to manufacture insurance coverage); Cummings v. Lyles, 27 N.E.3d 985, 991 (Ohio Ct. App. 2015) (stating that the insured's plea to felonious assault created a rebuttable presumption of intent to harm); Peerless Ins. Co. v. Viegas, 667 A.2d 785, 788-89 (R.I. 1995) (involving the sexual molestation of a minor and inferring the intent to harm as a matter of insurance law).

303. 739 N.E.2d at 447 .

304. Id.

305. Id.

306. Id.

307. Id.

308. Id. at 448 .

309. Id.

310. Id.

311. Id.

312. Id. 
that he intentionally shot Thomas Vinicky. ${ }^{313}$ By finding Savickas guilty of first degree murder, the jury in his criminal case "necessarily found him either to have intended to kill the victim, or at least to have known that his acts created a strong probability of death or great bodily harm." 314 That finding established that he "intended or expected' the result of his actions," which was the dispositive issue in the declaratory judgment action. ${ }^{315}$ There was a final judgment on the merits in Savickas's murder case-which he litigated to the hilt and to which he was obviously a party - and a determination of his mental state was essential to his conviction. ${ }^{316}$ Finally, the court saw no "potential unfairness to Savickas in estopping him with his criminal conviction." 317 After all, he had "a full and fair opportunity to litigate all relevant issues in his criminal trial, and did so." 318

The Savickas court concluded that American Family could collaterally estop Savickas with his criminal conviction which fixed his intent to harm Thomas Vinicky. ${ }^{319}$ As a result, the intentional acts exclusion in the American Family policy eliminated the insurer's duties to defend and indemnify Savickas. ${ }^{320}$ Furthermore, because Elizabeth Vinicky stood in Savickas's shoes as his assignee, she could have no greater rights under the American Family policy than he did. ${ }^{321}$ Thus, she was likewise precluded from claiming that Savickas negligently shot Thomas. ${ }^{322}$ In the end, the Savickas court reversed the appellate court and reinstated the trial court judgment for American Family. ${ }^{323}$

\section{Criminal Conviction Perfecting a Related Exclusion}

A liability policy may also include a criminal act, criminal conviction, or illegal act exclusion, and just as an insurer should be allowed to offer extrinsic evidence of an insured's criminal conviction to deny a defense based on the lack of an occurrence or the presence of an intentional acts exclusion, so should an insurer be able to offer extrinsic evidence to enforce a criminal act, criminal conviction, or illegal act exclusion. Pompa v. American Family Mutual Insurance Co. ${ }^{324}$ is a leading case on this point.

In September 2002, David Pompa killed Steven Domianus. 325 In May 2003 , Pompa pled guilty to criminally negligent homicide. ${ }^{326}$ When Domianus's heirs sued him for wrongful death, Pompa looked to his home-

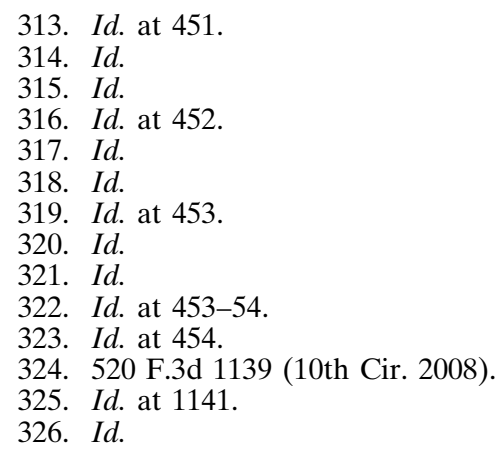


owner's insurer, American Family, for protection. ${ }^{327}$ American Family declined to defend or indemnify him based principally upon the criminal conviction exclusion in his policy, ${ }^{328}$ which provided that American Family would "not cover bodily injury or property damage arising out of . . . violation of any criminal law for which any insured is convicted." 329 The heirs subsequently won a judgment of nearly $\$ 1$ million against Pompa. ${ }^{330}$ Unable to satisfy the judgment, Pompa entered into a settlement agreement with the heirs in which he agreed to sue American Family for bad faith and assign to them the lion's share of any damages he recovered. ${ }^{331}$

Pompa sued American Family in a Colorado state court and American Family removed the case to federal court. ${ }^{332}$ American Family prevailed at summary judgment and Pompa appealed to the Tenth Circuit. ${ }^{333}$

On appeal, Pompa argued that the district court erred in considering his negligent homicide conviction in holding that American Family had no duty to defend him in the heirs' wrongful death case. ${ }^{334} \mathrm{He}$ contended that the district court should have evaluated American Family's duty to defend strictly according to the eight-corners rule. ${ }^{335}$ The Tenth Circuit, however, believed that the Colorado Supreme Court might well recognize an exception to the eight-corners rule if doing so did not undermine the rule's purposes. ${ }^{336}$ For example, the Colorado Supreme Court had seemingly suggested in a 2004 case, Cotter Corp. v. American Empire Surplus Lines Insurance Co. ${ }^{337}$ that it might recognize an exception to the eight-corners rule where the allegations in a plaintiff's complaint were designed to manufacture coverage. ${ }^{338}$

The Pompa court reasoned that this case fit within the exception to the eight-corners rule that the Cotter court had hinted it might consider. 339 Elaborating, the Pompa court made the case for the exception based on the facts presented:

Mr. Pompa's conviction is an indisputable fact that is not an element of either the cause of action or a defense in the underlying litigation (the wrongful-death case). Recognizing an exception in this circumstance would not undercut the policies supporting the complaint rule. First, it would not defeat the legitimate expectations of the insured to a defense, because an insured can have no reasonable expectation of a defense when an indisputable fact, known to all

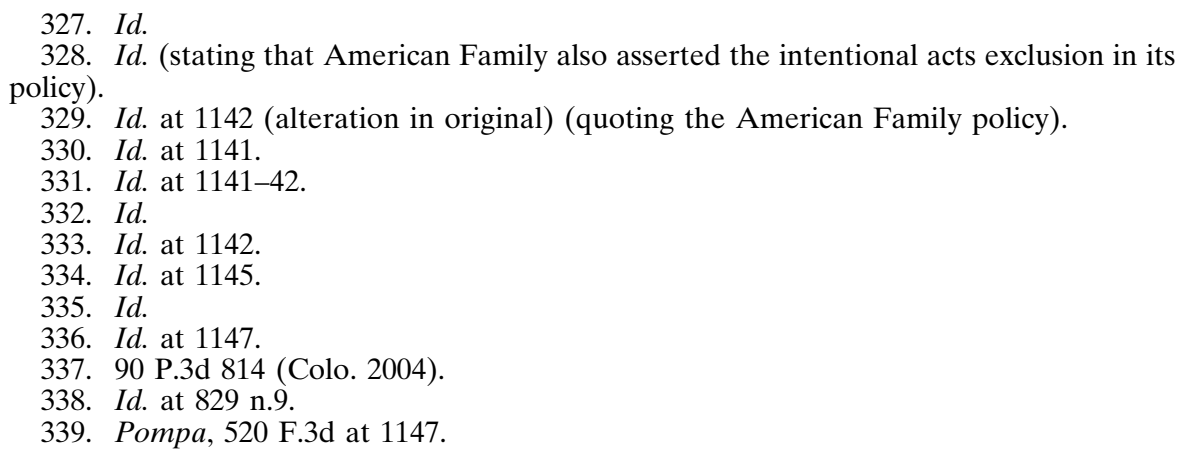


parties, removes the act in question from coverage. That the complaint made no mention of Mr. Pompa's conviction cannot turn an expectation of a defense in these circumstances into a reasonable one. Nor would recognition of this exception jeopardize the insured's defense in the underlying action, because the extrinsic fact is undisputed. ... Moreover, recognizing this exception serves a beneficial purpose: freeing an insurer from having to defend an action that from the outset clearly falls outside the policy's coverage . . . 340

The Pompa court acknowledged that the Colorado Supreme Court had never adopted this specific exception to the eight-corners rule, but nor had it ever been given the opportunity to do so. ${ }^{341}$ At the same time, the one exception to the eight-corners rule on which the Cotter court had expressly reserved judgment-a false allegation crafted to implicate insurance coverage-was "such a close cousin to the circumstance here" that the Pompa court was willing to assume that the Colorado Supreme Court would at least entertain it. ${ }^{342}$ "After all, the best evidence that an allegation triggering coverage is not bona fide is that it is indisputably untrue and is not necessary to establish liability in the underlying litigation." 343 The possible exception noted in Cotter would apply in this case if the heirs' wrongful death complaint had alleged that Pompa had not been convicted of Domianus's murder. ${ }^{344}$ That exception and the one the Pompa court was endorsing were "almost mirror images of one another." 345 Furthermore:

[I]f one adopts an interpretation of the complaint rule that is consistent with the notion of a complaint under the rules of civil procedure, our conclusion follows without any need to recognize an exception to the rule. When considering a motion to dismiss a complaint for failure to state a claim, Colorado courts may consider matters of which they can take judicial notice even if not mentioned in the complaint. In essence, judicially noticeable facts are incorporated into the complaint. Because the district court could have taken judicial notice of Mr. Pompa's conviction, that fact can be said to appear within the four corners of the complaint. ${ }^{346}$

Given Pompa's undisputed criminal conviction and the unambiguous criminal conviction exclusion in his homeowner's policy, American Family had no duty to defend him despite the negligence allegations in the plaintiffs' complaint. ${ }^{347}$ Accordingly, the Tenth Circuit affirmed summary judgment for American Family. ${ }^{348}$

340. Id. at $1147-48$.

341. Id. at 1148 .

342. Id. at 1148-49.

343. Id. at 1149 .

344. Id.

345. Id.

346. Id. (citation omitted).

347. Id.

348. Id. 


\section{CONCLUSION}

Under the eight-corners rule that many courts follow when deciding whether an insurer owes a duty to defend, insurers have historically been limited in their ability to use extrinsic evidence to excuse their duty to defend where the plaintiff's complaint or petition alleges facts that suggest the potential for coverage. In 2020, two Texas Supreme Court decisions tested the limits of the eight-corners rule and related limits on insurers' use of extrinsic evidence to excuse their duty to defend and helpfully illuminated this important and contentious issue. More broadly, and recognizing both the variations in law between jurisdictions and the typically fact-specific nature of decisions regarding insurers' duty to defend, it is reasonable to conclude that insurers may rely on extrinsic evidence to excuse their duty to defend in at least two situations beyond those involving fraud or collusion. First, an insurer should be able to deny a duty to defend where the extrinsic evidence relates exclusively to the issue of coverage under the policy. Second, an insurer should be allowed to use extrinsic evidence to excuse its duty to defend, even if the evidence arguably relates to the merits of the allegations against the insured, where the evidence is incontrovertible. 
